\title{
FAM20B-catalyzed glycosaminoglycans control murine tooth number by restricting FGFR2b signaling
}

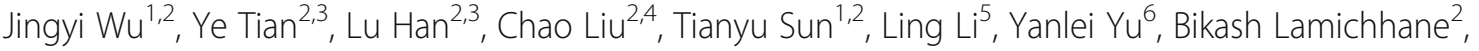 \\ Rena N. D'Souza ${ }^{7}$, Sarah E. Millar ${ }^{8}$, Robb Krumlauf9, 10, David M. Ornitz' ${ }^{5}$ Jian Q. Feng' ${ }^{2}$, Ophir Klein ${ }^{11,12}$, Hu Zhao², \\ Fuming Zhang ${ }^{6}$, Robert J. Linhardt ${ }^{6}$ and Xiaofang Wang ${ }^{2^{*}}$ (D)
}

\begin{abstract}
Background: The formation of supernumerary teeth is an excellent model for studying the molecular mechanisms that control stem/progenitor cell homeostasis needed to generate a renewable source of replacement cells and tissues. Although multiple growth factors and transcriptional factors have been associated with supernumerary tooth formation, the regulatory inputs of extracellular matrix in this regenerative process remains poorly understood.

Results: In this study, we present evidence that disrupting glycosaminoglycans (GAGs) in the dental epithelium of mice by inactivating FAM20B, a xylose kinase essential for GAG assembly, leads to supernumerary tooth formation in a pattern reminiscent of replacement teeth. The dental epithelial GAGs confine murine tooth number by restricting the homeostasis of Sox2(+) dental epithelial stem/progenitor cells in a non-autonomous manner. FAM20B-catalyzed GAGs regulate the cell fate of dental lamina by restricting FGFR2b signaling at the initial stage of tooth development to maintain a subtle balance between the renewal and differentiation of Sox2(+) cells. At the later cap stage, WNT signaling functions as a relay cue to facilitate the supernumerary tooth formation.
\end{abstract}

Conclusions: The novel mechanism we have characterized through which GAGs control the tooth number in mice may also be more broadly relevant for potentiating signaling interactions in other tissues during development and tissue homeostasis.

Keywords: Glycosaminoglycan, Proteoglycan, Fam20B, Kinase, Supernumerary teeth, Tooth renewal, Tooth replacement, Extracellular matrix, Stem cell, Sox2

\section{Background}

The ability to control stem/progenitor cell homeostasis is crucial for generating renewable source of replacement cells and tissues in regenerative medicine. A prerequisite for manipulating the renewal of stem cells is to understand the molecular mechanisms underlying the development of specific cell lineages and fates. The

\footnotetext{
* Correspondence: xfwang@tamu.edu

${ }^{2}$ Department of Biomedical Sciences, Texas A\&M University College of Dentistry, 3302 Gaston Ave, Dallas, TX 75246, USA

Full list of author information is available at the end of the article
}

developing tooth organ is an excellent model system for studying the molecular mechanisms and signaling pathways that regulate organogenesis. The hierarchical interactions between the dental epithelium and underlying dental mesenchyme represent a common paradigm in the development of ectodermal placodes deployed in diverse types of epithelium organogenesis, such as salivary glands, lungs, kidneys, mammary glands, hair follicles, and limb buds [1]. Conserved signaling pathways, including those mediated by WNTs, bone morphogenetic proteins (BMPs), fibroblast growth factors (FGFs), and

C The Author(s). 2020 Open Access This article is licensed under a Creative Commons Attribution 4.0 International License, which permits use, sharing, adaptation, distribution and reproduction in any medium or format, as long as you give appropriate credit to the original author(s) and the source, provide a link to the Creative Commons licence, and indicate if changes were made. The images or other third party material in this article are included in the article's Creative Commons licence, unless indicated otherwise in a credit line to the material. If material is not included in the article's Creative Commons licence and your intended use is not permitted by statutory regulation or exceeds the permitted use, you will need to obtain permission directly from the copyright holder. To view a copy of this licence, visit http://creativecommons.org/licenses/by/4.0/ The Creative Commons Public Domain Dedication waiver (http://creativecommons.org/publicdomain/zero/1.0/) applies to the data made available in this article, unless otherwise stated in a credit line to the data. 
sonic hedgehog $(\mathrm{SHH})$, are iteratively used in the cellcell and cell-matrix communications during tooth development [2]. The secreted morphogens of these cascades interact with extracellular components, such as proteoglycans, to potentiate signal transduction. Proper crosstalk and a fine balance within these signaling pathways are critical for modulating the progressive temporal processes of tooth development, including tooth initiation, morphogenesis, and renewal. While proteoglycans have been identified in murine teeth at various embryonic stages [3-7], their precise inputs into tooth development remain poorly understood.

Proteoglycans consist of a core protein and one or multiple covalently attached glycosaminoglycan (GAG) chains. Based on the disaccharide structures, the polysaccharide GAGs can be classified into heparan sulfate (HS)/heparin, chondroitin sulfate (CS), dermatan sulfate (DS), keratan sulfate (KS), and hyaluronan (HA). Various sulfotransferases give rise to many sulfation patterns and modify the saccharide backbone of sulfated GAGs. The sulfated GAGs are among the most highly negatively charged biopolymers in nature, and variation in the sequence and length of the chains gives rise to enormous polydispersity. This rich structural diversity enables GAGs to interact with various proteins, including components of signaling cascades such as FGFs, WNTs, BMPs, and HHs that are involved in stem/progenitor cell homeostasis [8].

Family with sequence similarity member 20-B (FAM20B) is a kinase that specifically phosphorylates the xylose in the common linkage region of GAGs. The xylose phosphorylation is essential for the linkage region assembly and subsequent GAG elongation [9]. Inactivating FAM20B kinase leads to truncated polysaccharide chains that cannot be further elongated due to impaired function of galactosyl transferase II [10]. This fundamental property of FAM20B provides an useful tool for investigating the molecular functions of GAGs in organogenesis. Given that constitutive inactivation of Fam20B results in embryonic death at E13.5 [11], we generated a Fam20B-floxed allele in mice to facilitate conditional knockout studies. We found that inactivating Fam $20 B$ in the dental epithelium led to supernumerary incisors that were formed in a manner similar to replacement tooth formation [12], uncovering a previously unknown function of GAGs in the control of tooth number. Our results demonstrate that the FAM20Bcatalyzed GAGs control the tooth number in mice by modulating the commitment of dental epithelial stem/ progenitor cells through a mechanism involving the restriction of FGFR2b signaling at the initial stage of tooth development. Our findings provide novel insights into the molecular mechanism regulating tooth number and renewal in mice that may shed light on other GAGmediated signaling events during organogenesis.

\section{Results \\ GAG deficiency in the dental epithelium leads to supernumerary incisors in mice}

It has been long known that proteoglycans are important molecules regulating signaling pathways during organogenesis. Decades ago, Thesleff et al. reported the expression of proteoglycans in developing murine teeth [13], and subsequent studies have identified multiple proteoglycans in both the dental epithelium and dental mesenchyme at various embryonic stages $[6,7,14-16]$. However, dissecting their mechanistic roles in tooth development has been challenging, because mice lacking individual proteoglycans or a particular type of GAGs did not show overt tooth phenotypes [17]. To explore this issue, we generated Fam20B-floxed mice to disrupt multiple GAGs in embryonic teeth in a tissue-specific manner.

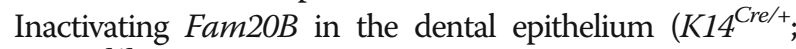
Fam $20 B^{f l / f f}$ ) led to formation of duplicate incisors ensuing the native ones, while the molar and diastema regions were not affected [12]. Histology and lineage tracing analyses revealed that the duplicate incisors initiate from an outgrowth of the lingual/mesial side dental lamina of the native enamel organ at the late cap stage ( E15.0) (Figs. 1E-H and 2N-Q). Of note is that both the native and duplicate incisors retained the ability of continuous growth and did not show apparent difference in the growth rate.

\section{Murine tooth number is specifically modulated by the GAGs in the dental epithelium}

Supernumerary teeth have been implicated with alterations of the interactions between the dental epithelium and dental mesenchyme [18]. Signaling changes in the dental mesenchyme frequently cause extra tooth formation, such as those in $\mathrm{Gas}^{-/-}$, Sostdc1 ${ }^{-/}$, Spry $^{-/-}, \mathrm{Wnt1}^{\mathrm{Cre}}$;Polaris ${ }^{\text {fllfl }}$, and $O s r 2^{-/-}$mice [19]. To investigate whether GAGs in the dental mesenchyme also play a role in controlling the tooth number in mice, we generated $\mathrm{Wnt}^{\mathrm{Cre} /{ }^{+}}$;Fam $20 \mathrm{~B}^{\mathrm{fl} / f l}$ mice to disrupt GAGs in the neural crest-derived mesenchymal cells. These mice did not show any changes in tooth number (Fig. 1I-L), although several mesenchyme-associated defects occurred as expected in their craniofacial complex [20]. This indicates that the murine tooth number is specifically modulated by the GAGs in the dental epithelium but not in the mesenchyme. Hence, we have focused on exploring its role in the dental epithelium.

\section{GAGs commit the cell fate of dental epithelium at the initial stage of tooth development}

Tooth development in mice initiates from a thickening of the dental epithelium at E10.5 to form a placode. The epithelial placode then invaginates into the dental mesenchyme to form a tooth bud, which further folds into an enamel organ in the following stages. In $\mathrm{K} 14^{\mathrm{Cre} /+}$; Fam $20 B^{f l f l}$ mice, the earliest sign of replacement tooth 


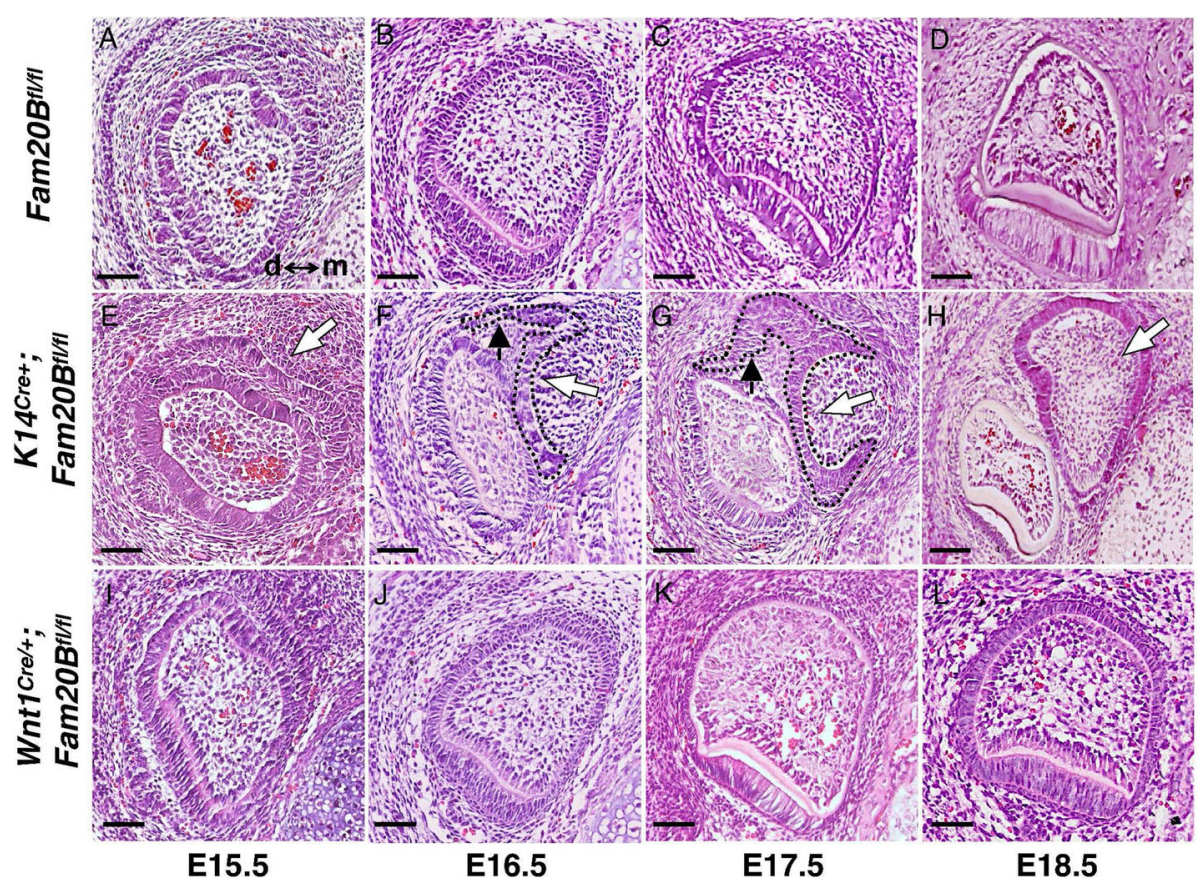

Fig. 1 GAGs in the dental epithelium but not in the dental mesenchyme determine the tooth number in mice. Hematoxylin-eosin (H\&E) staining on coronal sections of lower incisors from E15.5 to E18.5 mouse embryos. A-D Native enamel organs of incisors in normal control (Fam20B $B^{\text {fl/ff})}$ mice. $\mathrm{d} \leftrightarrow \mathrm{m}$ indicates the orientation of distal and mesial sides. $\mathbf{E}$ An ectopic thickening of dental epithelium (white arrow) was identified at the mesial-lingual side of the native enamel organ at E15.5 in $\mathrm{K}^{\mathrm{Cre} /+}$; Fam $20 \mathrm{~B}^{\mathrm{fl} / \mathrm{fl}}$ mice. F, G The ectopic thickening of dental epithelium formed an extended dental lamina (black arrows) at the mesial-lingual side of native enamel organs and developed into a novel enamel organ (white arrows and dashed lines) at the end of the extended lamina. H At E18.5, the extended dental lamina disappeared, and the extra enamel organs developed into supernumerary incisors (white arrow) at the mesial-lingual side of native teeth. I-L In contrast, disrupting GAGs in the dental mesenchyme did not cause any extra teeth in the $\mathrm{Wnt}^{\mathrm{Cre} / \mathrm{t}}$;Fam20B ${ }^{\mathrm{fl} / \mathrm{fl}}$ mice. Scale bars: $50 \mu \mathrm{m}$

formation appeared at the late cap stage $(\sim \mathrm{E} 15.5)$ as an ectopic placodal thickening of the dental epithelium at the mesial-lingual side of the native enamel organ (Fig. 1EH). TUNEL and EdU incorporation analyses on earlier stages showed overproliferation in both the dental epithelium and dental mesenchyme and reduced apoptosis in the dental epithelium at the lingual/mesial side of native enamel organs starting at $\sim \mathrm{E} 12.5$ in the $\mathrm{K} 4^{\mathrm{Cre} /+}$; $\mathrm{Fam} 20 \mathrm{~B}^{\mathrm{fl} / \mathrm{ll}}$ mice (Fig. 2A-M). This suggests that the cell fate of the GAG-deficient dental epithelium had been changed prior to the cap stages. To determine a precise timing of the cell fate change, we employed a Tet-On system to knockout Fam $20 B$ from the dental epithelium at different embryonic stages. The results demonstrated that replacement tooth formation was induced only if Fam $20 B$ was inactivated within a time window between E10.5 and E12.5 (Additional File 1: Fig. S1) (Table 1). This implies that the cell fate of primary dental lamina was committed by FAM20Bcatalyzed GAGs at the initial stage of tooth development.

\section{GAGs control murine tooth number by restricting the renewal of Sox2(+) cells in the dental epithelium}

Sox2-expressing stem/progenitor cells are believed to contribute to the whole enamel organ tissues during tooth development $[21,22]$. In $\mathrm{cKO}\left(\mathrm{K}_{14}{ }^{\mathrm{Cre} /+}\right.$; Fam $20 B^{f l / f l} ;$ Sox $2^{G F P}$ ) mice, the Fam $20 B$-deficient incisors showed progressively increasing expression of ectopic Sox2 at the lingual side of enamel organ from E13.5 to E15.5. In contrast, the Sox2 signal gradually vanished from the lingual side of the enamel organ in control incisors $\left(\mathrm{K} 4^{\mathrm{Cre} /+} ; \mathrm{Fam}_{20 \mathrm{~B}^{f l /+}} ; \mathrm{Sox} 2^{\mathrm{GFP}}\right)$ during these stages (Additional File 2: Fig. S2). At E16.5, the normal enamel organ completely lost Sox $2(+)$ expression (Fig. 2P), while the cKO mice showed large amount of Sox $2(+)$ cells in both the lingual side of the native enamel organ, the dental lamina and the enamel organ of the supernumerary teeth (Fig. 2Q). These results suggest that GAG deficiency in the dental epithelium leads to ectopic or extended renewal of Sox $2(+)$ stem/progenitor cells.

Subsequently, we deleted Sox 2 from the dental epithelium of $\mathrm{K} 14^{\mathrm{Cre} / \mathrm{H}}$;Fam $20 \mathrm{~B}^{\text {fl/fl }}$ mice by introducing the Sox $2^{f l / f l}$ allele to examine the contribution of Sox2(+) progenitor cells to the supernumerary tooth formation in the GAG-deficient teeth. The resultant mice showed partial rescue of the supernumerary tooth phenotype as well as a reduced size of the native teeth (Additional File 3: Fig. S3). To further explore the regulatory input of GAGs on the renewal of Sox $2(+)$ cells, we deleted 


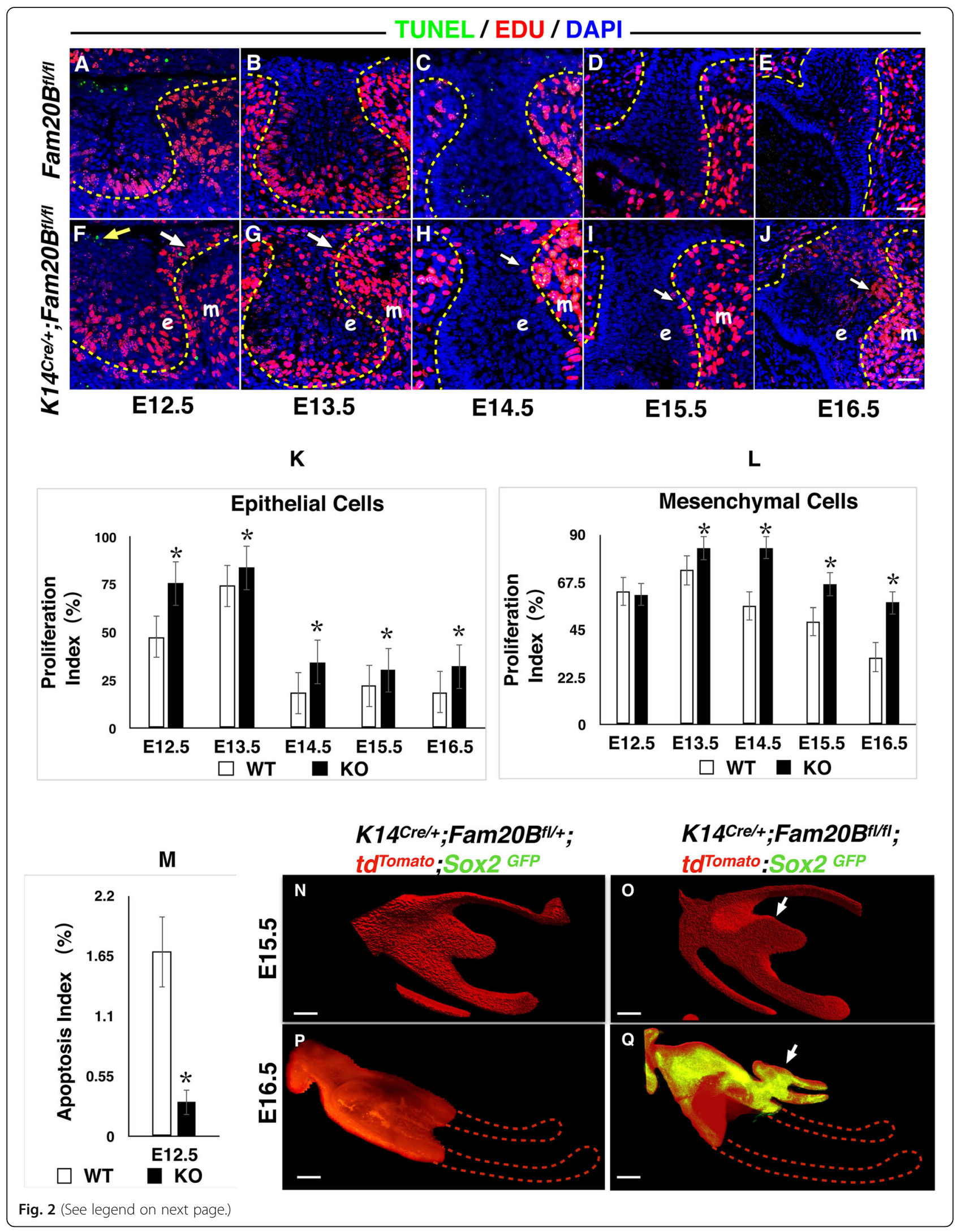


(See figure on previous page.)

Fig. 2 Cell fate change and ectopic renewal of Sox $2(+)$ cells in the dental epithelium of $K 14^{\mathrm{Cre} / \mathrm{t}} ;$ Fam $20 \mathrm{~B}^{\mathrm{fl} / \mathrm{fl}}$ mice. A-M GAG deficiency in the dental epithelium led to ectopic over-proliferation and less apoptosis in the native incisors. EdU incorporation analysis showed ectopic overproliferation (white arrows in $\mathbf{F}-\mathbf{J}$ ) in the GAG-deficient dental epithelium (e, plotted by dashed lines) and dental mesenchyme $(\mathrm{m})$ at the mesial/ lingual side of native incisors in the presumptive location of supernumerary teeth formation starting at E13.5 compared to the normal control mice (2-sample $t$ tests, $P<0.05$ ). TUNEL assay revealed reduced apoptosis (yellow arrow) in GAG-deficient dental epithelium at E12.5 (2-sample $t$ tests, $P<0.01)$. $\mathbf{N}-\mathbf{Q}$ Three-dimensional reconstruction of lower incisor confocal images after tissue clearing of mandibles. td ${ }^{\text {Tomato }}$ indicates the dental epithelium. GFP indicates the Sox2(+) cells. On the sagittal sections of E15.5 incisors (N, O), an ectopic thickening of dental epithelium was identified at the lingual side of the native enamel organ in $\mathrm{K} 4^{\mathrm{Cre} /{ }^{+}} ; \mathrm{Fam} 2 \mathrm{OB}{ }^{\mathrm{fl} / \mathrm{fl}}$ mice (arrow) compared to the normal control. The slight bulge (white arrow) at the lingual side of the enamel organ in the Fam20B-mutant mice indicates the initiation of the supernumerary tooth outgrowth. At E16.5 (P, Q), Sox2(+) cells showed ectopic renewal in the Fam20B-deficient native enamel organ and actively contributed to the development of successive enamel organ (arrow). In contrast, the normal controls had lost Sox2 expression at this stage. The dashed lines in (P) and (Q) outlined the remaining parts of the enamel organs that were not able to be displayed due to the working distance of the confocal. Scale bars: $25 \mu \mathrm{m}$ in $(\mathbf{A}-\mathbf{J}) ; 50 \mu \mathrm{m}$ in $(\mathbf{N}-\mathbf{Q})$

Fam20B from the Sox2(+) population at E11.5 using Sox2-CreER, the efficiency of which was validated by crossing with tdTomato indicator (Additional File 4: Fig. S4A). The Sox $2^{\mathrm{CreER}}$;Fam $20 B^{f l / f l}$ mice did not recapitulate the supernumerary tooth phenotype (Additional File 4: Fig. S4B), suggesting that FAM20B-catalyzed GAGs restrict the renewal of Sox2(+) cells in a nonautonomous manner.

\section{GAGs determine the cell fate of dental epithelium by restricting FGFR2b signaling}

Multiple signaling pathways, such as those mediated by WNTs, FGFs, BMPs, and HH, have been implicated in cell fate commitment in embryonic teeth [23, 24]. To begin to investigate the molecular mechanisms by which GAGs determine the cell fate of dental epithelium, we systematically screened signaling pathways potentially associated with the phenotype at the initial stage of tooth development using immunohistochemistry, in situ hybridization, and signaling reporter lines in mice. We did not detect significant changes in WNT and BMP signaling in the Fam20B-mutant incisors (Additional Files 5 and 6: Figs. S5 and S6). However, we identified a hyperactivation of FGF in the Fam20B-deficient incisors at E12.5 and E13.0, as indicated by a robust upregulation of Pax9, Etv-5, and p-ERK in the dental epithelium and/or dental mesenchyme (Fig. 3). In agreement with this, the transcription of Shh, a downstream gene of FGF signaling [25], showed an expanded scope of expression at the presumptive location of replacement teeth formation in the GAG-deficient dental epithelium. Accordingly, two SHH downstream markers in the dental mesenchyme, Gli1 and Patched1, showed broader responses to the epithelial $\mathrm{HH}$ signaling, as indicated by Gli1- and Ptch1-LacZ indicator mice (Fig. 4).

Several FGFs and their receptors are expressed in incisors during the critical time window (E11.5-E12.5) identified in the Fam20B-mutant mice for supernumerary tooth formation: FGF1, FGF2, and FGF9 are present in the dental epithelium, while their primary receptor, FGFr1c, is expressed in the dental mesenchyme. FGF10 is localized in the dental mesenchyme whereas its receptor, FGFr2b, is exclusively present in the dental epithelium [26] (Additional File 7: Fig. S7). The complementary expression pattern between FGF ligands and their receptors requires FGFs to diffuse to the counterpart location/tissue to perform their functions. We excluded several FGFs and their receptors based on their incongruent expression pattern and timing. For example, FGF8 was excluded for lacking an expression in incisors during this stage, while FGF3 and FGF4 were excluded for their expression timing later than E13.5, etc.

Table 1 Supernumerary teeth formed when Fam2OB inactivation was induced between E10.5 and E12.5

\begin{tabular}{|c|c|c|c|}
\hline Induction time & $\begin{array}{c}\text { Mice with } \\
\text { Supernumerary teeth }\end{array}$ & $\begin{array}{c}\text { Mice without } \\
\text { Supernumerary } \\
\text { teeth }\end{array}$ & Tested animals \\
\hline $\mathrm{E} 10.5$ & $21(100 \%)$ & 0 & 21 \\
\hline $\mathrm{E} 11.5$ & $17(94 \%)$ & 1 & 18 \\
\hline $\mathrm{E} 12.5$ & $9(31 \%)$ & 20 & 29 \\
\hline $\mathrm{E} 13.5$ & 2 & 16 & 18 \\
\hline $\mathrm{E} 14.5$ & 0 & 7 & 7 \\
\hline
\end{tabular}




\section{Fam20Bfl/fl}
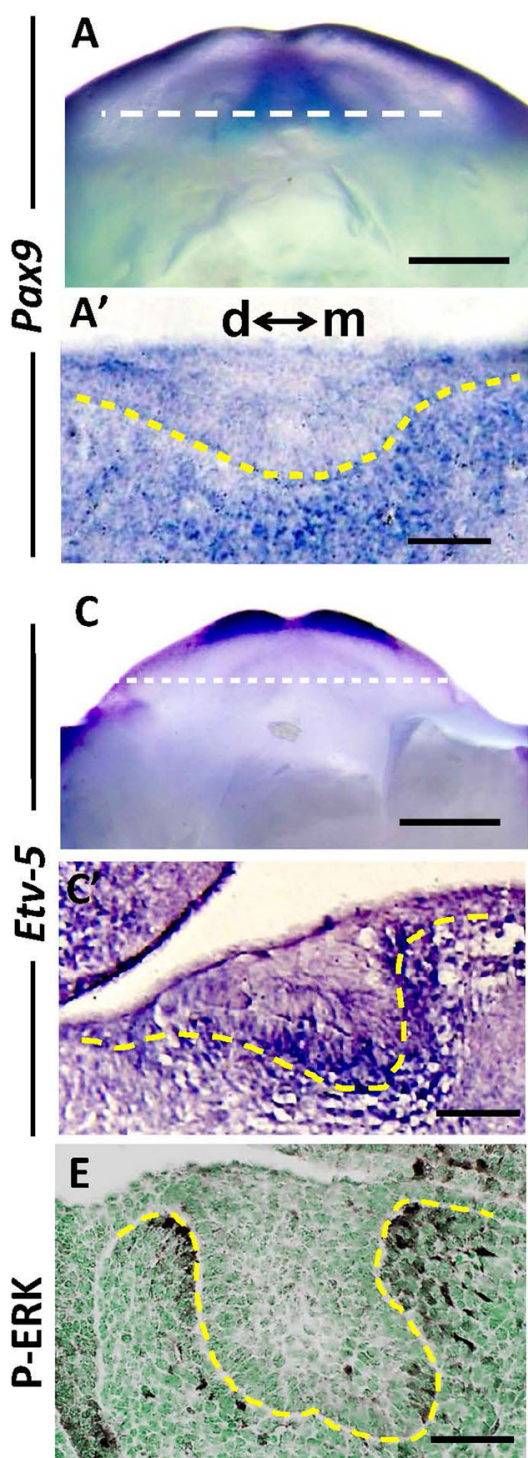

K14 ${ }^{\text {Cre/ }} ;$ Fam20B fl/fl $^{\prime}$

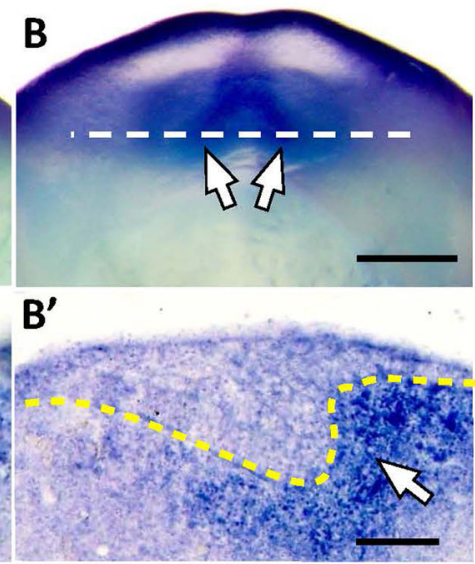

D
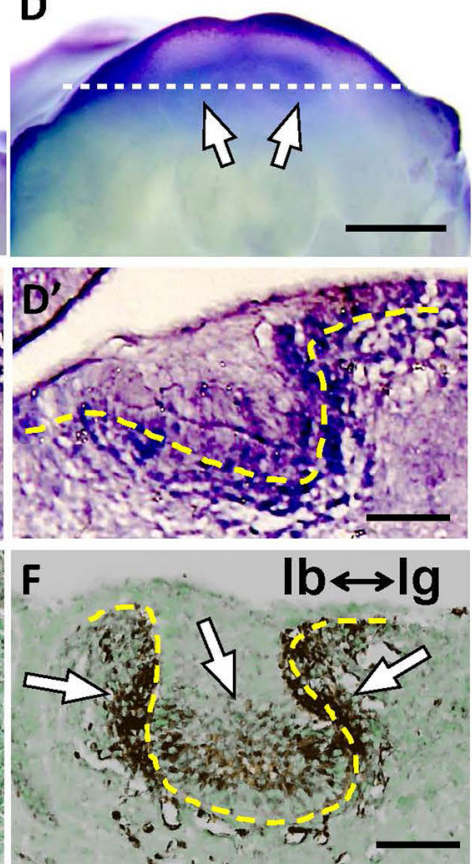

Fig. 3 FGF signaling was overactivated in the GAG-deficient incisors. A-D In situ hybridization of E12.5 whole mount mandibles. A'-D' Coronal sections through the dashed white lines in (A-D). The yellow dotted lines indicate the border between the dental epithelium and the dental mesenchyme. $\mathrm{d} \leftrightarrow \mathrm{m}$ indicates the orientation of distal and mesial sides. In the GAG-deficient incisors, Pax9 was upregulated at the mesial side of dental mesenchyme (arrow), and Etv5 showed stronger expression in both the dental epithelium and the dental mesenchyme. E, $\mathbf{F}$

Immunohistochemistry staining of sagittal sections of E13.0 lower incisors showed an upregulation of p-ERK in both the dental epithelium and dental mesenchyme in the Fam20B-deficient incisors (white arrows). Ib $\leftrightarrow$ g indicates the orientation of labial and lingual sides. Scale bars: $250 \mu m$ in whole mount $\mathbf{A}-\mathbf{D} ; 50 \mu \mathrm{m}$ in sections $\mathbf{A}^{\prime}-\mathbf{D}^{\prime}$ and $\mathbf{E}, \mathbf{F}$

It is well documented that FGFs in the dental epithelium and the dental mesenchyme stimulate one another via a positive feedback loop, which is negatively regulated by Sprouty [27, 28]. Previous studies indicated that inactivation of Sprouty led to supernumerary teeth in both diastema and incisor regions due to epithelium $\leftrightarrow-$ mesenchyme bidirectional hyperactivity of FGF, in which FGF10/FGFr2b signaling appeared to play a major role compared with FGF3/FGFr1c [27].
To determine whether the hyperactivated FGF signaling underlies the cell fate change of the GAG-deficient dental epithelium associated with the extra teeth formation, we employed a Tet-On system to inhibit FGFR2b signaling through overexpressing an FGFR2b inhibitor (dominantnegative FGFR-HFc protein) [29] in the Fam20B-deficient dental epithelium. Overexpression of the FGFR2b inhibitor successfully rescued the supernumerary tooth phenotype (Fig. 5) and clearly exhibited a trend whereby earlier 


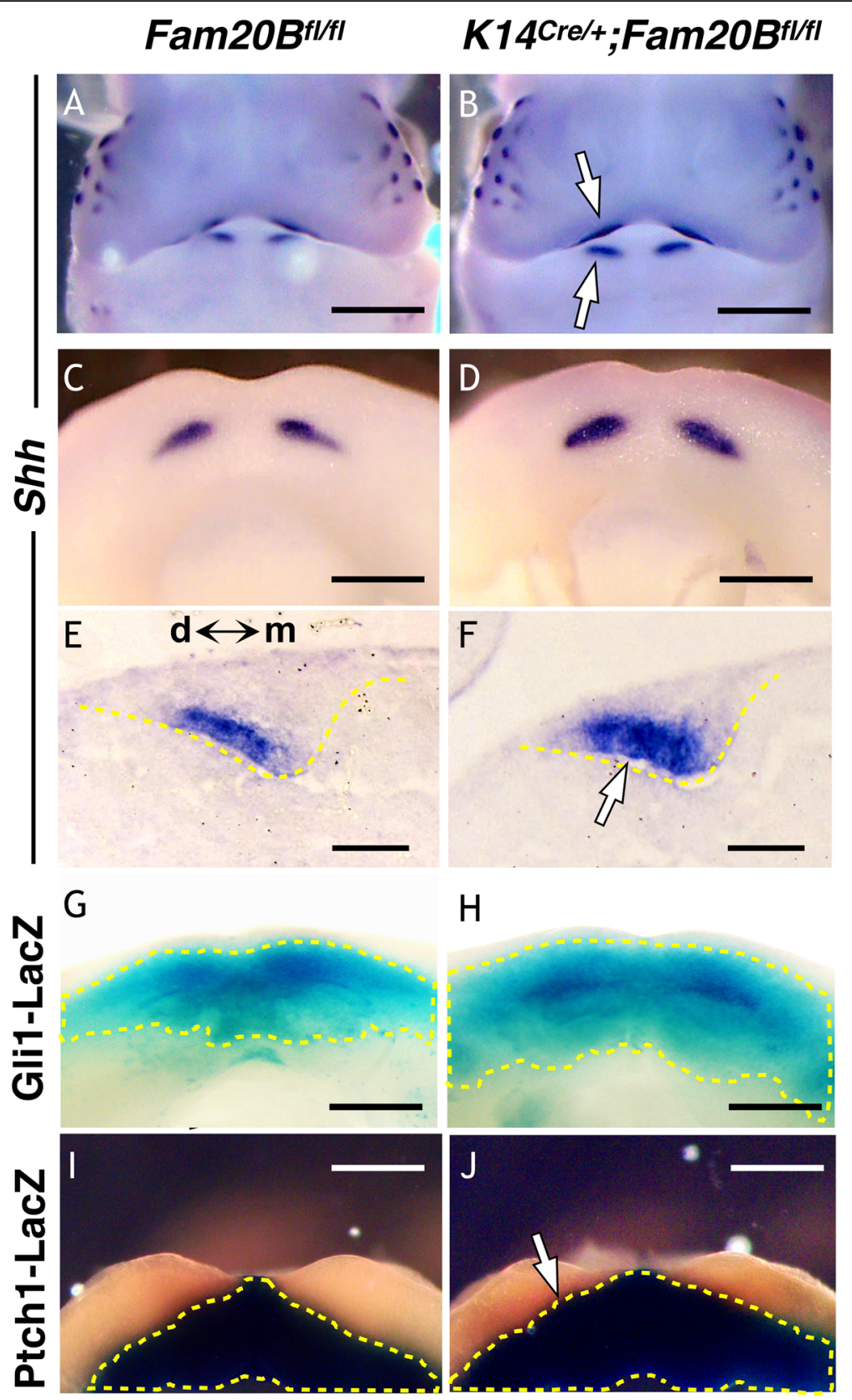

Fig. 4 SHH signaling was overactivated in the GAG-deficient incisors. A-D Whole mount in situ hybridization of E12.0 mouse embryos showed an

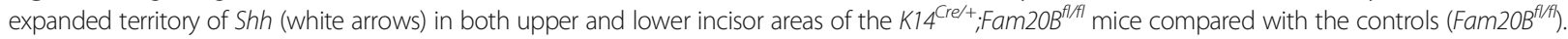
Note that Shh signal in hair follicles can be used as internal references for the comparison between knockout and control mice. E, F ISH of Shh on the coronal sections of lower incisors showed an expanded expression of Shh in the GAG-deficient dental epithelium toward the mesial side (white arrow)

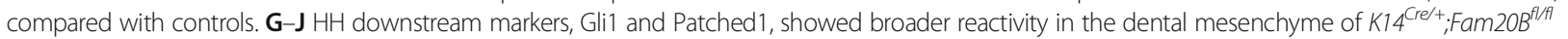
mice, as indicated by Gli1- and Ptched1-LacZ indicators (dashed lines plotted). Scale bars: $500 \mu \mathrm{m}$ in $\mathbf{A}$ and $\mathbf{B} ; 250 \mu \mathrm{m}$ in $\mathbf{C}, \mathbf{D}$ and $\mathbf{G}-\mathbf{J} ; 50 \mu \mathrm{m}$ in $\mathbf{E}$ and $\mathbf{F}$

inhibition resulted in better rescue effects (Table 2). In agreement with this, inhibiting FGFr2b signaling in the Fam20B-deficient dental epithelium also reduced the expression scope of $S h h$ back to the normal size (Additional File 8: Fig. S8), indicating that Shh is downstream to the FGF hyperactivation that initiates the supernumerary tooth formation. These results collectively indicate that FAM20B- catalyzed GAGs control the cell fate of dental epithelium by confining the FGF10/FGFR2b signaling at the initial stage of tooth formation. The confining effects are most likely associated with FGF10/FGFr2b reactivity/transmission but not their expression, because RNAScope assays of Fgf10 and Fgfr $2 b$ did not detect any changes in the Fam20B-deficient incisors (Additional File 7: Fig. S7). 
A
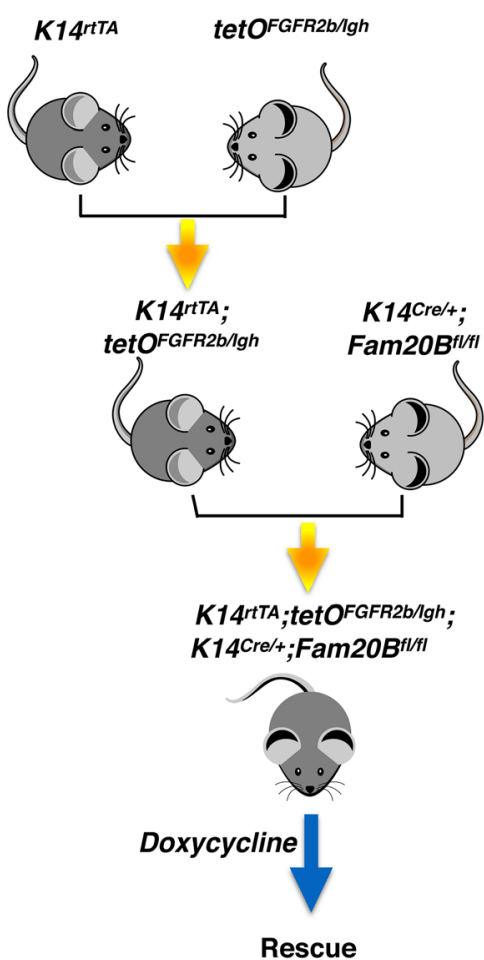

Rescue

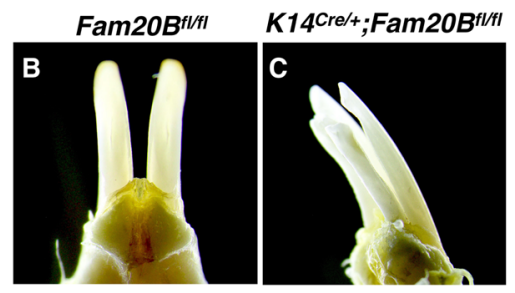

K14Cre/+;Fam20B ${ }^{\text {fl/fl} ; K 14 r t T A ; t e t O F G F r 2 b-I g h ~}$

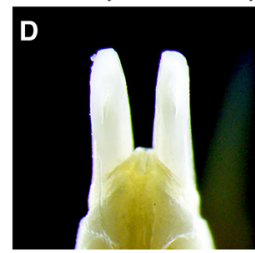

Fully rescued

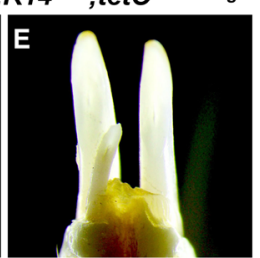

Partially rescued

Fig. 5 Inhibiting FGFR2b rescued the supernumerary tooth phenotype. a The schematic depicts the rescue strategy of supernumerary tooth formation by inhibiting FGFR2b with a dominant-negative FGFR2b inhibitor through a tetO system. The $K 14^{\text {rTTA }}$, tetO ${ }^{\text {FGFr2b/lgh }}$, and

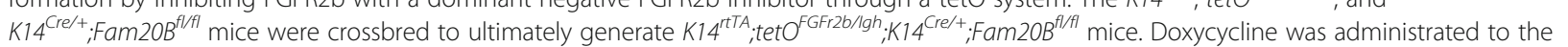
resultant mice at $2 \mathrm{mg} / \mathrm{kg}$ at designated time points (E10.5-E14.5) to induce the expression of the dominant-negative FGFR2b inhibitor, FGFR2b/ Igh, in the GAG-deficient dental epithelium. b-e Inhibiting FGFR2b in the dental epithelium fully (D) or partially (E) rescued the supernumerary tooth phenotype in the $\mathrm{K} 14^{\mathrm{Cre} /+}$; Fam $2 \mathrm{OB}{ }^{\mathrm{fl} / \mathrm{fl}}$ mice

GAGs may regulate FGFR2b signaling by confining the diffusion gradient of FGF10

In order to determine how FAM20B loss of function affects GAG assembly in the dental epithelium, we compared the GAG profile of Fam20B-deficient dental epithelium with WT using a newly developed GAG profiling method that relies on multiple reaction monitoring liquid chromatography mass spectrometry (MRMLCMS) [30]. The amount of HS, CS, and total GAGs were remarkably reduced in the Fam20B-deficient dental epithelium (Fig. 6A), whereas their total composition did not show apparent changes (Fig. 6B). The HS composition in the Fam20B-deficient dental epithelium showed reduced NS and increased $0 S$ (Fig. 6C), while the CS composition in Fam20B-deficient dental epithelium did not show apparent differences from the WT (Fig. 6D).

GAGs may regulate growth factor signaling in various manners, including shaping the diffusion gradients and mediating the interactions between the growth factors and their receptors [31]. In a recent study, we revealed

Table 2 The timing and effects of inhibiting FGFR2b in rescuing the supernumerary tooth formation in Fam20B-deficient mice

\begin{tabular}{|c|c|c|c|c|}
\hline Induction time & Fully rescued & Partially rescued & Not rescued & Tested animals \\
\hline E10.5 & $6(46 \%)$ & $7(53 \%)$ & 0 & 13 \\
\hline E11.5 & $3(23 \%)$ & $8(69 \%)$ & 1 & 13 \\
\hline E12.5 & $2(11 \%)$ & $14(77 \%)$ & 3 & 18 \\
\hline E13.5 & 0 & 1 & 6 & 7 \\
\hline E14.5 & 0 & 0 & 6 & 6 \\
\hline
\end{tabular}




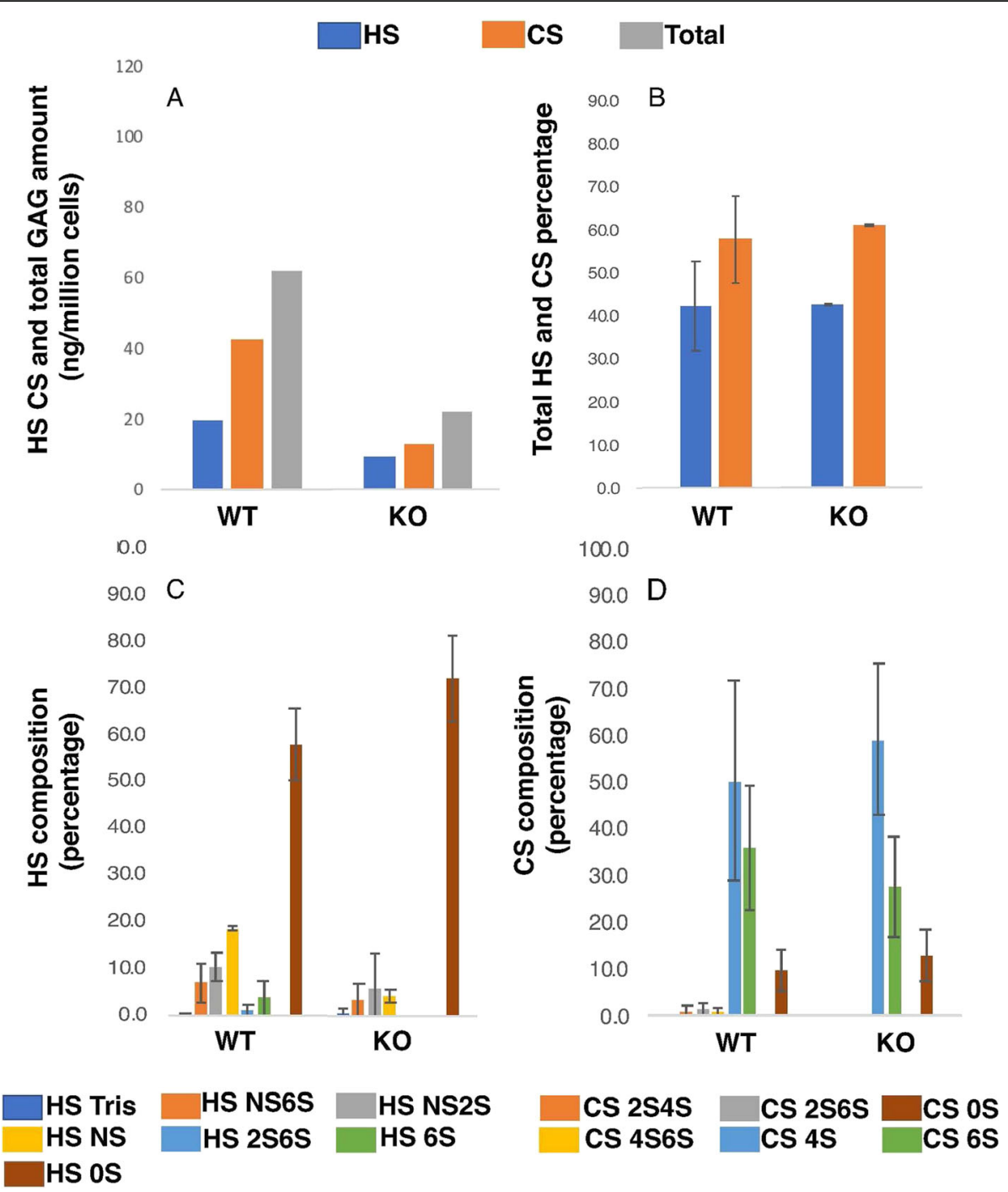

Fig. 6 GAG profiling of Fam20B-deficient dental epithelium. A The amount of HS, CS, and total GAGs were remarkably reduced in the Fam20Bdeficient dental epithelium compared to the WT $(n=1)$. B The HS and CS composition relative to the total GAGs were similar between KO and WT $(n=2)$. C Detailed HS composition showed reduced NS and increased OS in the Fam20B-deficient epithelium $(n=2)$. D CS composition in the KO did not show apparent differences from the WT $(n=2)$. The analytical error was $\sim 3 \%$ for these samples

that the interactions between FGF10 and heparin are chain-length dependent, and the minimum binding size for the interactions is dp6 [32]. As cells lacking FAM20B cannot extend GAGs beyond the tetrasaccharide linkage and form very short saccharides [10], we estimate that the truncated saccharides of FAM20B-mutant GAGs cannot bind FGFs. In this case, we assayed the interactions between FGF10 and FAM20B non-mutant GAGs (heparin, HS, DiS HS, TriS HS, and CSA) at variable concentrations $(0.00,0.02,0.08,0.30,1.25$, and $5.00 \mu \mathrm{g} / \mathrm{ml})$ in solution culture of BaF3 cells that had been engineered to report FGFR2b reactivity [33]. Heparin served as a positive control in the assays for its known synergistic effects on FGFr2b signaling [34]. Our results showed that none of the tested GAGs, except for the positive control heparin, had significant synergistic or inhibitory effects on FGFR2b signaling (Additional File 9: Figs. S9A and S9B), indicating that GAGs may not restrict FGF10-FGFR2b signaling through modulating ligand-receptor interactions.

Given the complementary expression pattern between FGF10 and FGFr2b, FGF10 needs to diffuse to the dental epithelium to perform its function. We built a hydrogel cell culture system mimicking the ECM environment to test if GAGs (CSA, CSB, HS, Des-2S heparin, and Des-6S heparin) confine the diffusion of FGF10 at certain concentrations $(1 \mu \mathrm{g} / \mathrm{ml}, 3 \mu \mathrm{g} / \mathrm{ml}$, and $5 \mu \mathrm{g} / \mathrm{ml}$ ) (Fig. 7 and Additional File 10: Fig. S10). We focused on the $2 \mathrm{~S}$ and $6 \mathrm{~S}$ since these functional groups are critical in FGF interactions. The requirements of NS and NAc were examined in testing heparin and HS. GAGs at $1 \mu \mathrm{g} / \mathrm{ml}$ and $3 \mu \mathrm{g} / \mathrm{ml}$ displayed 
A

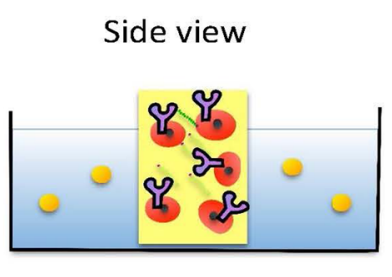

Top view

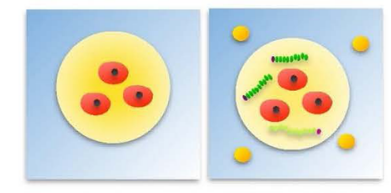

Blank Control FGF +GAG

FGF10 Ligand $叉$ FGFR2b BaF3 ……, GAGs

Hydrogel

RPMI1640

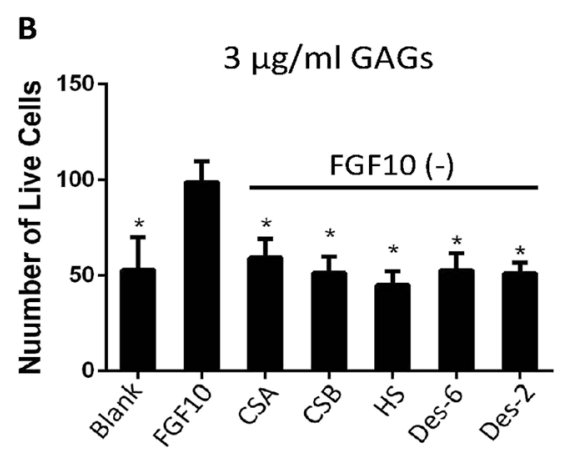

C

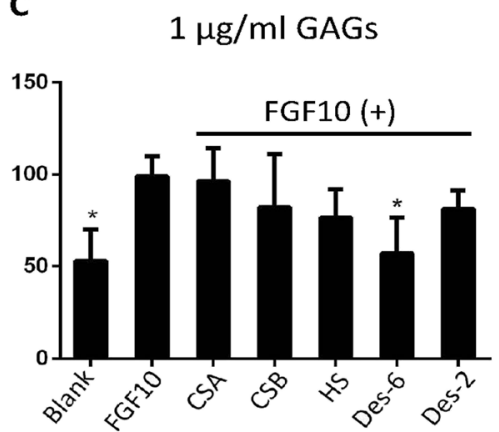

D

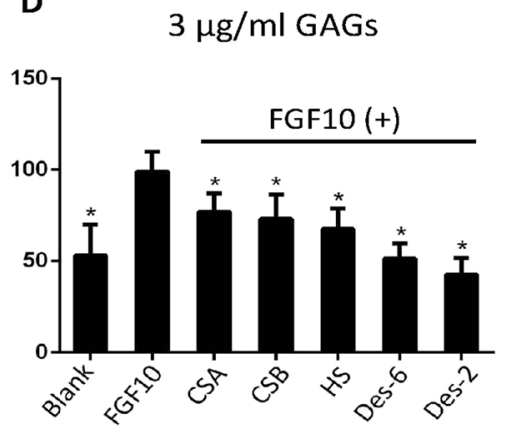

E

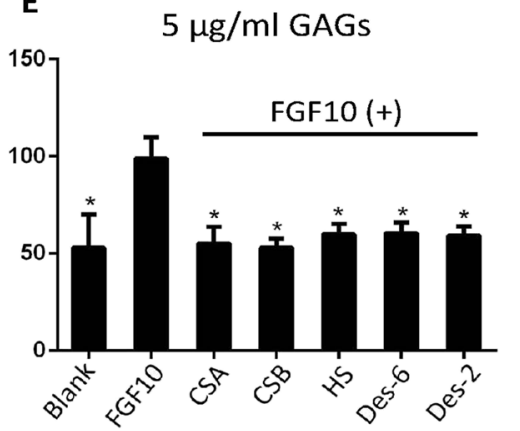

Fig. 7 GAGs restrict the diffusion gradient of FGF10. a A hydrogel cell culture system was built to mimic the ECM environment. BaF3-FGFR2b cells were embedded in hydrogel with or without GAGs and cultured in RPMI1640 media. Cultures without GAGs in the hydrogel were divided into blank control or FGF10 control according to the presence or absence of 1000 pM FGF10 in the culture medium. The experimental groups were supplemented with 1000 pM FGF10 in the culture medium plus $1 \mu \mathrm{g} / \mathrm{ml}, 3 \mu \mathrm{g} / \mathrm{ml}$, or $5 \mu \mathrm{g} / \mathrm{ml}$ of GAGs in the hydrogel. After $48 \mathrm{~h}$ of culture, the FGF activity of each group was calculated based on the viability of BaF3-FGFR2b cells (see Additional File 10: Fig. S10). b Cultures with GAGs in the hydrogel without FGF10 in the medium showed no significant differences from the blank control, indicating that GAGs alone did not affect the viability of BaF3 cells. c, d GAGs at $1 \mu \mathrm{g} / \mathrm{ml}$ and $3 \mu \mathrm{g} / \mathrm{ml}$ concentrations displayed differential config effects on FGF reactivity. e GAGs at $5 \mu \mathrm{g} / \mathrm{ml}$ showed nearly equal confining effects on FGF reactivity. The cell viability of each experimental group (named after supplemented GAGs) was compared with FGF control by 2-sample $t$ tests. Data are mean $\pm \mathrm{SD}(n=3) .{ }^{*} P<0.05$ indicates a significant difference between experimental group and FGF10 Control

differential confining effects on FGF10 diffusion (Fig. 7c, d). In particular, $3 \mu \mathrm{g} / \mathrm{ml}$ GAGs confined FGF10 diffusion in a preference pattern: Des-2 heparin > Des-6 heparin $>\mathrm{HS}>$ CSB > CSA (Fig. 7d), and $1 \mu \mathrm{g} / \mathrm{ml}$ GAGs showed a similar preference pattern except for Des-2 heparin displaying a reduced confining effect (Fig. 7c). At $5 \mu \mathrm{g} / \mathrm{ml}$, all tested GAGs showed almost equally strong inhibition on FGF10 diffusion (Fig. 7e). These data collectively suggest that GAGs differentially confine the diffusion of FGF10 based on their composition and sulfation states in a dose-dependent manner.

Hyperactivated WNT signaling serves as a relay cue in the GAG-mediated supernumerary tooth formation

Subsequent to the cell fate commitment of the GAGdeficient dental lamina, we identified an ectopic hyperactivation of canonical WNT signaling in the dental epithelium and adjacent dental mesenchyme at the lingual/mesial side of the native enamel organ starting at E14.5 ( 1 day before the thickening of the extra dental lamina). This is demonstrated by an ectopic expression of LEF-1 (Fig. 8AF) and BAT-GAL indicator (Fig. 8G, H) compared to the control mice. Conversely, a WNT inhibitor, Sostdc1, was downregulated in the dental follicle at the presumptive location of the supernumerary teeth (i.e., at the lingual/mesial side of native enamel organ) (Fig. 8I, J). The molar regions did not show WNT hyperactivity (data not shown).

We employed a Tet-On system to overexpress DKK1 [35], a WNT inhibitor in the Fam20B-deficient dental epithelium at E13.5 to determine the biological significance of the WNT hyperactivation in supernumerary tooth formation. The $D k k 1$ transgene fully rescued the tooth phenotype in the $\mathrm{K}_{14^{\mathrm{Cre} /+}}$; Fam $20 \mathrm{~B}^{\text {fl/fl }}$ mice (Fig. $8 \mathrm{~K}-\mathrm{M})$, indicating that the ectopic hyperactivation of WNT signaling is essential for accomplishing the supernumerary tooth formation. However, the upregulation of WNT signaling is not a direct consequence of GAG deficiency, because inactivating Fam $20 B$ in the dental epithelium at E13.5 ( $\sim 1$ day before the overactivation of WNT in the $\mathrm{K} 14^{\mathrm{Cre} /+}$;Fam $20 B^{f l / f l}$ mice) did not cause 


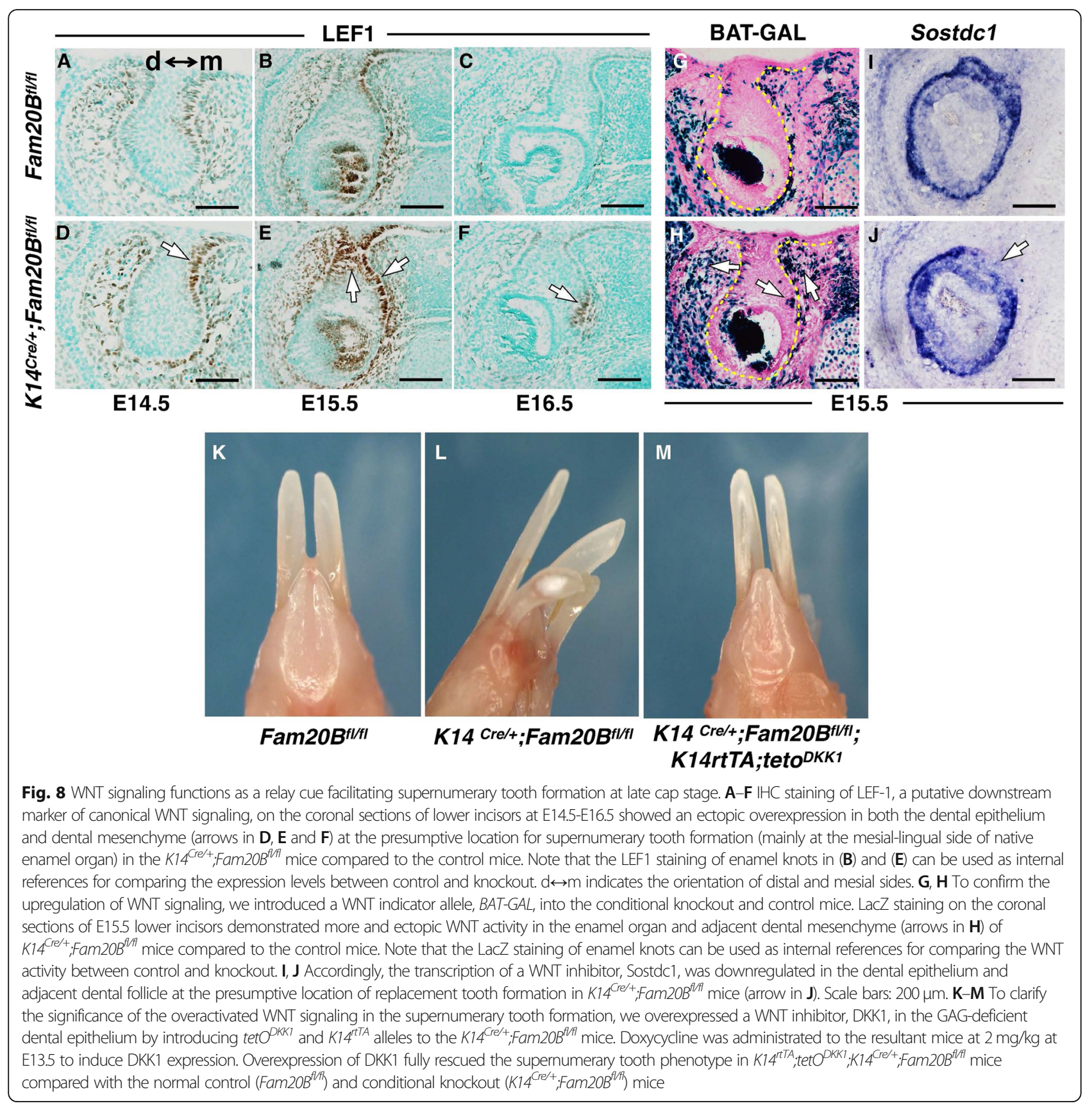

supernumerary tooth formation or any WNT activity changes as indicated by $B A T^{G A L}$ indicator (cKO mice

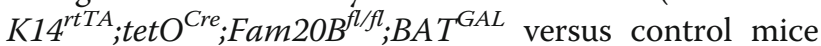
$\mathrm{K}_{14}{ }^{r t T A} ;$ tet $\mathrm{O}^{\mathrm{Cre}} ; \mathrm{Fam} 20 \mathrm{~B}^{\mathrm{fl/}+} ; B A T^{G A L}$ ) (data not shown). These results collectively suggest that the ectopic hyperactivation of WNT is a secondary reaction to the GAG deficiency in the dental epithelium and a relay cue for accomplishing the supernumerary tooth formation.

\section{Discussion}

Interplay between growth factors is involved in the hierarchical and iteratively used signaling cascades that guidetooth development. These secreted proteins interact with extracellular components to transmit signaling intracellularly. Although accumulating evidence shows that proteoglycans in the extracellular matrix and on the cell surfaces are pivotal signaling regulators for the morphogenesis of multiple organs, their role in tooth development remains poorly understood. In this study, we demonstrate a novel molecular mechanism for how dental epithelium is pre-programmed by GAGs in the control of tooth number in mice. FAM20B-catalyzed GAGs control murine tooth number by committing the cell fate of dental epithelial stem/progenitor cells. This is achieved through restriction 
of FGFR2b signaling at the initial stage of tooth development. At the cap stages, WNT signaling then relays relevant cues to complete the replacement tooth formation (Fig. 9A, B).

The supernumerary incisors in Fam20B-mutant mice initiate from an outgrowth of the lingual/mesial part of the native enamel organs at the late cap stage. This growth pattern is very similar to the supernumerary incisors in Sostdc1-mutant mice, which also originate from part of the native teeth, reminiscent of replacement tooth formation [36]. Of note is that Sostdc1-mutant mice also develop diastema teeth that are derived from revitalized diastema rudiments [37], and the gene profile change associated with the extra tooth formation is very different from that in the Fam20B-mutant mice. Previous studies showed that epithelial stabilization of canonical WNT signaling revitalizes the rudiments in molar and diastema regions [38-41]. In the Fam20B-knockout mice, the WNT hyperactivity is confined to the incisor regions starting at the late cap stage and appeared to be a secondary reaction to the hyperactivity of FGF signaling at the initial stage, because removing Fam $20 B$ from the dental epithelium at the cap stage failed to induce FGF/WNT hyperactivity and supernumerary teeth. These discrepancies suggest intrinsic differences between the development of molars and incisors and illustrate the complexity of the regulatory mechanism for the control of murine tooth number.

Sox2-expressing stem/progenitor cells in the dental epithelium are believed to hold the odontogenic potency in different modes of tooth development, including tooth initiation, tooth replacement, and the continuous growth of rodent incisors [19-23, 42]. The role of Sox2(+) cells in the labial cervical loop of murine incisors represents a paradigm of organ renewal derived by adult stem cells [21-23, 43-45]. FGF8 in the stellate reticulum of the cervical loop is believed to maintain the Sox $2(+)$ population in the postnatal incisors [21]. However in embryonic teeth, it remains unclear if a similar molecular mechanism applies to the Sox $2(+)$ population that initiates tooth replacement. Our genetic analyses reveal that the GAGdeficient incisors revived tooth replacement-like capacity but retained the continuous growth, and there were no growth rate differences between the native and replacement incisors. This indicates that the Sox $2(+)$ cells are differentially regulated for tooth renewal and tooth replacement in the cervical loop of postnatal incisors and in the dental epithelium of embryonic teeth.

FGF10-FGFR2b signaling has been associated with stem cell recruitment and maintenance in multiple tissues [4649]. In embryonic teeth, FGF10 is dominantly present at the initial stage of tooth development [26]. Overexpressing FGF10 in zebrafish produces supernumerary and bicuspid teeth [28]. We found that FAM20B-catalyzed GAGs inhibit tooth replacement of murine incisors by confining the renewal of Sox2(+) cells in the dental epithelium via restricting FGFR2b signaling. This provides genetic evidence that the Sox $2(+)$ cells in the embryonic teeth are differentially regulated by FGFs compared to those in the postnatal teeth. Hence, they modulate different tooth renewal patterns in the processes underlying tooth replacement versus continuous growth in mice.

Although the lineage tracing in this study clearly indicates that Sox $2(+)$ cells contribute to the supernumerary tooth formation in GAG-deficient incisors, deleting Sox 2 from Fam20B-deficient dental epithelium only partially rescued the phenotype. Sanz-Navarro et al. [50] also observed mild tooth phenotypes when they removed Sox2 from Shh $(+)$ population in the dental epithelium. They speculated that it may be related to the mosaic activation of Shh-Cre and/or redundancy from other Sox members. Together with our data, it appears that Sox2 is dispensable in the dental epithelium for odontogenesis, although it is an excellent marker for the dental epithelial stem/progenitor cells.

Previous studies have identified undersulfated GAGs on pluripotent embryonic stem cells (ESCs) whereas highly sulfated GAGs on differentiated cells, indicating that the sulfation pattern of GAGs are implicated with the progression of ESCs from self-renewal to a differentiated state [51, 52]. An explanation is that the stemness of ESCs is protected from the growth factor signaling by a shield of minimally sulfated GAGs [51]. However, this mechanism may not apply to the stem/progenitor cells in the dental epithelium of mice. The sulfation loss in the dental epithelial GAGs could be a secondary effect that is derived from the dramatic reduction of GAGs. More importantly, the undersulfated GAG remnants in the Fam20B-deficient dental epithelium appeared not to shield growth factors, because FGF signaling was upregulated rather than downregulated/abolished.

Accumulating evidence shows that HS/heparin 6-O- and 2-O-sulfo groups modulate FGF10-mediated epithelial morphogenesis and differentiation (such as those in submandibular and lacrimal glands) by increasing the affinity of FGF10 to FGFR2b, which forms an FGF10-FGFR2b-HS ternary signaling complex to result in diverse biological outcomes [53-55]. When Hs2st (heparan sulfate 2-O-sulfotransferase) and $H_{s 6 s t}$ (heparan sulfate 6-O-sulfotransferase 1) were both inactivated, the formation of FGF10-FGFR2bheparan sulfate complex was disrupted on the cell surface and completely abolished lacrimal gland development [54]. In Fam20B-knockout mice, there was no apparent reduction of endogenous HS 6-O- and 2-O-sulfo groups in the Fam20B-deficient dental epithelium. An assumptive disruption of the FGF10-FGFR2b-HS complex in the Fam20B-deficient dental epithelium indeed promoted rather than attenuated FGF10-FGFR2b signaling. This in turn promoted the renewal but not differentiation of the Sox $2(+)$ stem/progenitor cells, strongly suggesting an inhibitory role 


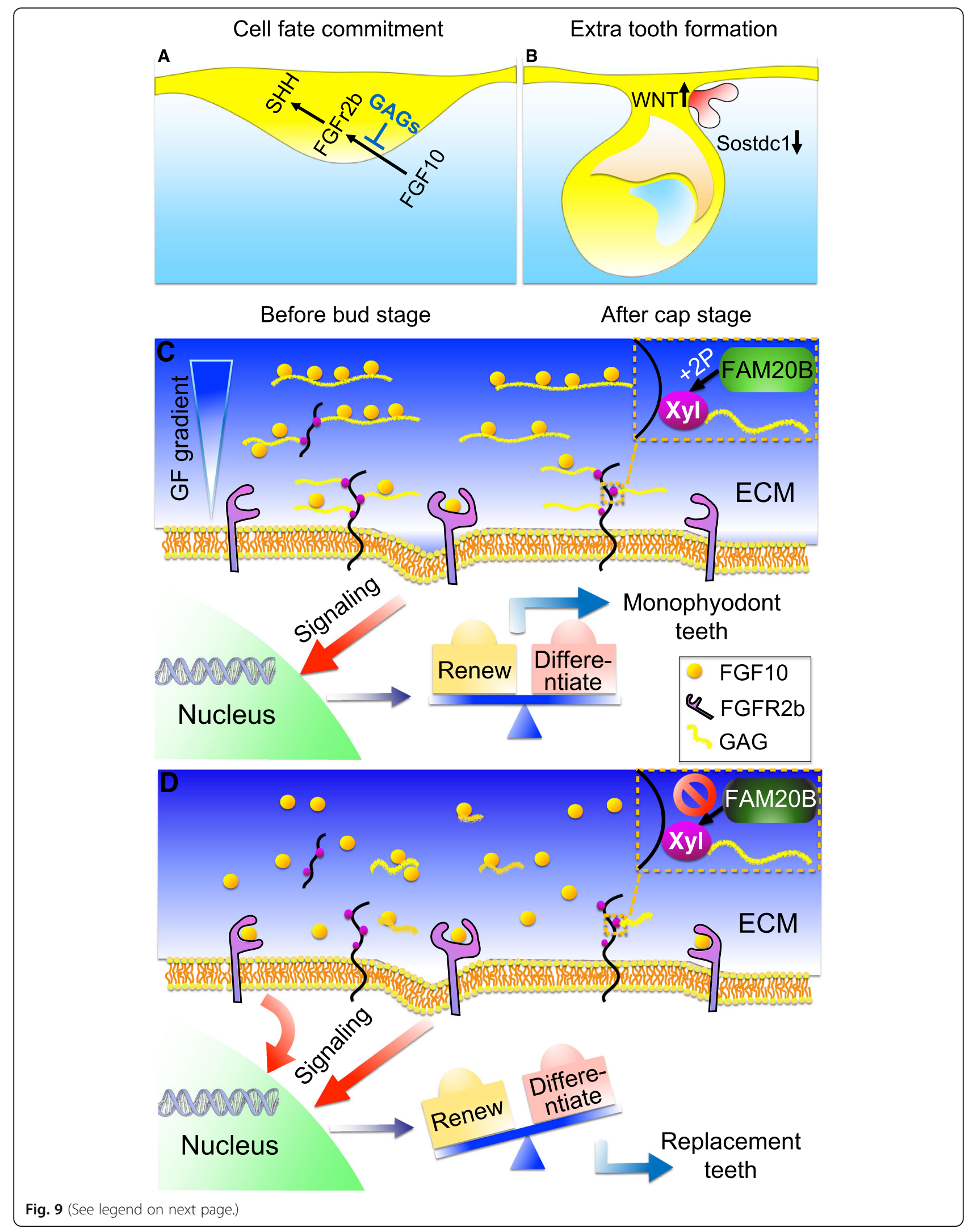


(See figure on previous page.)

Fig. 9 Hypothetic mechanism by which GAGs restrict tooth number in mice. A At the initial stage of tooth development, FAM20B-catalyzed GAGs commit the cell fate of dental epithelium by restricting the diffusion gradient of FGF10 from dental mesenchyme into dental epithelium in the process of activating FGFR2b signaling. B At late cap stage, overactivated WNT signaling plays as the relay cue to facilitate the supernumerary tooth formation. C Under normal condition, FAM20B phosphorylates the xylose in the linkage region of GAGs, which is essential for GAG assembly. GAGs in the ECM and on the cell surface interact with FGF10 ligands to shape a restricted diffusion gradient, which is essential for controlling the FGFR2b-mediated signaling balance between the renewal and differentiation of Sox2(+) stem/progenitor cells in the dental epithelium. D Inactivation of Fam20B in the dental epithelium leads to GAG deficiency, which facilitates FGF10 diffusion and access to FGFR2b. The upregulated FGFR2b signaling overweighs the renewal of Sox2(+) cells in the dental epithelium, leading to replacement-like tooth formation in monophyodont mice

of GAGs on FGF10-FGFR2b signaling. Our results suggest that GAGs in the dental epithelium are unlikely to inhibit FGF10-FGFR2b signaling by serving as co-receptors. Instead, they may regulate the signaling by sequestering FGF10 to restrict the diffusion gradient. The differential regulation of FGF10-FGFR2b signaling between the dental epithelium and other epithelium-derived organs also illustrates that GAG-mediated regulation of growth factors is highly dependent on the biological context.

It is interesting to note that the biological effects of GAG deficiency were very specific in Fam20B-deficient dental epithelium despite the broad spectrum of proteins potentially interacting with GAGs. Similar phenomenon has been observed in many other GAG-deficient animal models [17]. The specificity of GAG-growth factor interaction may be derived from a specific polysaccharide sequence, a polysaccharide conformation, an accurate control of enzymatic modification on saccharides, or a dominant presence of growth factors in certain biological context [56]. A prerequisite to answering these questions will require the development of oligosaccharide libraries with systematically varied structures and more sophisticated GAGosome analyses, such as oligosaccharide mapping and sequencing, which are emerging technologies [57].

In summary, this study reveals that FAM20B-catalyzed GAGs determine the monophyodont phenotype in mice by restricting the capacity for renewal of dental epithelial stem/ progenitor cells through inhibition of FGFR2b signaling at the initial stage of tooth development. The GAGs interact with FGF ligands to shape a restricted diffusion gradient of FGF10, which maintains a subtle balance between the renewal and differentiation of Sox2(+) cells in the dental epithelium. Disrupting GAG assembly breaks this balance by overactivating FGFR2b signaling, which overweighs the renewal of Sox $2(+)$ cells and initiates the replacement tooth formation in monophyodont mice (Fig. 9C, D).

\section{Conclusion}

In conclusion, this study demonstrates that the FAM20Bcatalyzed GAGs control the number of murine teeth by regulating the commitment of dental epithelial stem/progenitor cells through a mechanism involving the restriction of FGFR2b signaling at the initial stage of tooth development. This novel mechanism may also be more broadly relevant for potentiating signaling interactions in other tissues during development and tissue homeostasis.

\section{Materials and methods \\ Animals}

All of the animal experiments were carried out according to the protocol approved by the Institutional Animal Care and Use Committee of Texas A\&M University College of Dentistry (Dallas, TX, USA) and performed in accordance with the NIH Guide for the Care and Use of Laboratory Animals.

Fam $20 B^{\text {flox/flox }}$ mice and Tet $O^{D k k 1}$ micewere generated as previously described [12, 35]. BRE-LacZ mice were kindly gifted by Dr. Leif Oxburgh (Maine Medical Center Research Institute). Mice purchased from Jackson Laboratory (Bar Harbor, MN, USA): K14 ${ }^{\text {Cre }}$ (stock \#004782), Wnt1 ${ }^{\text {Cre } 2}$ (stock \#022137) [58], K14 ${ }^{\text {rtTA }}$ (stock \#008099) [59], TetO ${ }^{\text {Cre }}$ (stock \#006224) [60], TetO ${ }^{\text {FGFr2b/Igh }}$ (stock

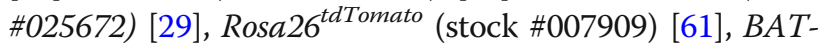
GAL (stock \#005317) [62], Gli1 ${ }^{\text {LacZ }}$ (stock \#008211) [63], Ptch $^{\text {LacZ }}$ (stock \#003081) [64], Sox $2^{\text {GFP }}$ (stock \#017592) [65], Sox $2^{\text {CreER }}$ (stock \#017593) [65], and Sox $2^{\text {flox }}$ (stock \#013093) [66]. Genotyping were carried out as previously described [12] or following Jackson Lab's instructions.

Pregnant mice were fed with Doxycycline chow (1 g/ $\mathrm{kg}$, Bio-Serv, NJ, USA) and water $(2 \mathrm{mg} / \mathrm{ml}$, Sigma, St. Louis, MO, USA) at designated time points for 3 consecutive days to induce TetO transgene expression. Tamoxifen (T5648, Sigma, St. Louis, MO, USA) was injected to pregnant mice intraperitoneally at $50 \mathrm{mg} / \mathrm{kg}$ at designated time points for 3 consecutive days to induce CreER expression.

\section{Tissue preparation}

Embryonic stage was determined according to the vaginal plug (day 0.5 ) and confirmed by morphological criteria. Mouse embryos of desired stages were harvested in diethyl pyrocarbonate (DEPC)-treated Dulbecco's phosphate-buffered saline (PBS). Dissected heads from the embryos were fixed with $4 \%$ paraformaldehyde (PFA) in $0.1 \%$ diethyl pyrocarbonate(DEPC)-treated PBS at $4{ }^{\circ} \mathrm{C}$ overnight and decalcified in $0.1 \%$ DEPC-treated $15 \%$ EDTA (pH 7.4) at $4{ }^{\circ} \mathrm{C}$ for 1 to 2 days as needed, 
then dehydrated in a serial gradient of ethyl alcohol solutions followed by paraffin embedding.

\section{Tissue clearing and 3D imaging}

Mandibles for 3D-image reconstruction were collected from 6 embryos of $\mathrm{KO}$ or control mice at each desired time point. Tissue clearing was performed on the mandibles as previously described [67]. Fluorescent images were acquired with Zeiss LSM780 two-photon microscopy (Visible laser lines: 488,633 nm). Image processing and 3D rendering were performed with Imaris 9.0 (Bitplane) as previously described [67].

\section{Immunohistochemistry (IHC)}

Immunohistochemistry staining was performed on $4-\mu \mathrm{m}$ thick coronal sections prepared from 6 mandibles of $\mathrm{KO}$ or control mice using a DAB substrate kit (Vector Laboratories, Burlingame, CA, USA) following the manufacturer's instruction. The primary antibodies used for immunohistochemistry are: anti-phospho-ERK (9101, 1:200, Cell Signaling, Danvers, MA, USA), anti-Lef1 (C12A5, 1: 200 , Cell signaling, Danver, MA, USA), anti- $\beta$-catenin (sc7963, Santa Cruz), anti-Sox2 (ab97959, Abcam, Cambridge, MA, USA), and anti-phospho-SMAD1/5 (9516, Cell Signaling). Methyl green was used for counterstaining.

\section{In situ hybridization (ISH)}

ISH was performed following previously descripted protocols $[68,69]$. For section ISH, the paraffin-embedded samples were prepared as $10-\mu \mathrm{m}$-thick serial sections. For whole-mount ISH, the properly fixed embryos were bleached with $3 \% \mathrm{H}_{2} \mathrm{O}_{2}$ followed by dehydration in methanol. Plasmids containing the cDNAs of mouse Shh, Pax 9, Msx-1, Sostdc1, and Wnt5a, were linearized with appropriate restriction enzymes. The cDNA of Etv-5 was generated by RT-PCR using the total RNA extracted from E13.5 mouse embryos and designed primers (Forward: AGTGGCCGCTCAGGAGTA; Reverse: AGCTATTTAG GTGACACTATAGACAGTAATCTCGGGG CTCCT). The sense and antisense probes were synthesized using an RNA Labeling Kit (Roche; Indianapolis, IN). The probes were detected by an enzyme-linked immunoassay with an anti-DIG-AP antibody conjugate (Roche, Indianapolis, IN, USA) and stained with BM Purple (Roche) for positive signals. The DIG-labeled sense probes were used in place of the antisense probes in the negative control experiments. The results were examined and photographed using an Olympus RX43 upright microscope and an SZX16 stereo microscope (Olympus, Waltham, MA, USA) connected with a DP27 imaging system (Olympus).

\section{RNAScope and quantitation}

RNAScope was performed using the RNAscope $2.5 \mathrm{HD}$ Brown Reagent Kit (322300, Advanced Cell Diagnostics,
Neward, CA, USA) on 5- $\mu \mathrm{m}$ FFPE tissue sections prepared from 6 mandibles of $\mathrm{KO}$ or control mice according to the manufacturer's instructions. Slides were baked for $1 \mathrm{~h}$ at $60{ }^{\circ} \mathrm{C}$ prior to use. After de-paraffinization and dehydration, the tissues were air dried and treated with peroxidase blocker before boiling at $100-104{ }^{\circ} \mathrm{C}$ in target retrieval reagents for $15 \mathrm{~min}$. Protease was then applied for $30 \mathrm{~min}$ at $40^{\circ} \mathrm{C}$. Target probes Fgf10, Fgfr 2 b, and Fgf9 (446371, 806301, 499811, Advanced Cell Diagnostics) were hybridized for $2 \mathrm{~h}$ at $40^{\circ} \mathrm{C}$, followed by a series of signal amplification and washing steps. All hybridizations at $40^{\circ} \mathrm{C}$ were performed in a HybEZ Hybridization System. RNA staining signal was identified by $\mathrm{DAB}$ as brown chromogenic dots. Following the RNAscope assay, samples were counterstained for $2 \mathrm{~min}$ with hematoxylin. Each sample was quality controlled for RNA integrity with a probe specific to the housekeeping gene cyclophilin B (PPIB); only samples with an average of $>4$ dots per cell were included for analysis. Negative control background staining was evaluated using a probe specific to the bacterial dapB gene; only samples with an average of $<1$ dot per 10 cells were included for analysis. Bright field images were acquired by Olympus CKX41 inverted microscope using a $\times 40$ objective.

For semi-quantitation analysis, the RNAscope signal is scored on the basis of number of dots per cell as follows: $0=0 \mathrm{dot} / \mathrm{cell}, 1=1-3 \mathrm{dots} / \mathrm{cell}, 2=4-10 \mathrm{dots} / \mathrm{cell}, 3=$ $10-15 \mathrm{dots} /$ cell, and $4=>15 \mathrm{dots} /$ cell with $>10 \%$ of dots in clusters. To evaluate heterogeneity in marker expression, $H$-score analysis is performed. The $H$-score is calculated by adding up the percentage of cells in each scoring category multiplied by the corresponding score, so the scores are on a scale of 0-400. The RNAscope signal area proportion of each probe is quantified by Image J based on $\times 20$ tooth bud images $(250 \times 180 \mu \mathrm{m})$.

\section{Cell proliferation assay (EdU) and TUNEL staining}

Timed pregnant mice were injected intraperitoneally with EdU at $15 \mu \mathrm{g} / \mathrm{kg}$ in PBS (C10352, Invitrogen, Carlsbad, CA, USA). After $1 \mathrm{~h}$ of injection, embryo heads were collected and processed for paraffin embedding and section. EdU incorporation was detected on $5-\mu \mathrm{m}-$ thick paraffin sections using a Click-iT Kit (Invitrogen) following the manufacturer's protocol. Apoptotic cells were identified on the sections by TUNEL staining using an ApopTag Plus In Situ Apoptosis Fluorescein Detection Kit (S7111, Millipore, Burlington, MA, USA) according to the manufacturer's instruction. DAPI was used as counterstaining. Mounted sections were examined and photographed using an SP5 confocal microscope (Leica, Buffalo Grove, IL, USA).

\section{X-Gal staining}

The embryos for whole-mount X-Gal staining were fixed with $0.2 \%$ glutaraldehyde in PBS at $4{ }^{\circ} \mathrm{C}$ for $30 \mathrm{~min}$. After 
three wash in $0.005 \%$ NP-40 and $0.01 \%$ sodium deoxycholate, the embryos were incubated in staining solution ( $5 \mathrm{mM}$ potassium ferrocyanide and potassium ferricyanide, $2 \mathrm{mM} \mathrm{MgCl}, 0.4 \% \mathrm{X}$-Gal in dimethylformamide) at $37^{\circ} \mathrm{C}$ for $3-24 \mathrm{~h}$, followed by post-fixation with $4 \%$ paraformaldehyde (PFA) in PBS at room temperature for $1 \mathrm{~h}$. Embryos for cryosection were fixed in 4\% PFA for 1-2 h at room temp and dehydrated in $30 \%$ sucrose at $4{ }^{\circ} \mathrm{C}$ overnight, then embedded in OCT for cryosection. XGal staining was performed on the cryosections, and nuclear fast red was used for counterstaining.

\section{GAG profiling}

GAG profile of E11.5 dental epithelium in WT and Fam20B-deficient $(\mathrm{KO})$ mice were characterized regarding the GAG type, amount, sulfation, and disaccharide composition using a recently developed method MRM-LCMS (multiple reaction monitoring liquid chromatography mass spectrometry) [70]. Briefly, the dental epithelium of lower incisors was isolated from the mandibles of E11.5 $\mathrm{KO}$ and WT embryos after dispase digestion $(1.8 \mathrm{U} / \mathrm{ml}$ in $\mathrm{Ca}$ - and Mg-free PBS, Gibco) at $37^{\circ} \mathrm{C}$ for $30 \mathrm{~min}$. The epithelium pooled from 6 embryos of each group were lysed in digestion buffer $(50 \mathrm{mM}$ ammonium acetate, $2 \mathrm{mM}$ calcium chloride) and digested by cocktail of GAG-lyases (heparin lyase I, II, III, and chondroitin lyase ABC (10 mU each), then placed in $37^{\circ} \mathrm{C}$ incubator overnight. The resulting disaccharides were recovered by centrifugal filtration, labeled with 2-aminoacridone (AMAC), and analyzed by liquid chromatography mass spectrometry (LC-MS/MS, Thermo Inc.) running at multiple reaction monitoring mode. The separation was carried out with an Agilent 1200 HPLC separation system on an Agilent Poroshell 120 ECC18 column $(3.0 \times 150 \mathrm{~mm}, 2.7 \mu \mathrm{m}$, Agilent, USA $)$ at $45^{\circ} \mathrm{C}$. The analytical error for GAG profiling was $<3 \%$.

\section{Cell culture}

The BaF3 cells used in this study were engineered to stably express FGFR2b [71]. The cells were maintained in RPMI 1640 culture media (Gibco Life Science, Gaithersburg, MD, USA) supplemented with $10 \%$ newborn calf serum (Gibco), $0.5 \mathrm{ng} / \mathrm{ml}$ murine recombinant interleukin-3 (Gibco), $2 \mathrm{mM}$ L-glutamine, penicillin/streptomycin $(\mathrm{P} / \mathrm{S})$, and $50 \mathrm{nM} \beta$ mercaptoethanol (Gibco). The cells were treated with G418 $(600 \mu \mathrm{g} / \mathrm{ml}$, Gibco) for 2 weeks before being used for the subsequent assays.

\section{Cell proliferation assay}

BaF3-FGFR2b cells $\left(4 \times 10^{4}\right)$ were seeded in each well of 96-well plates in culture medium without interleukin-3. The culture medium was supplemented with or without $1.5 \mu \mathrm{g} / \mathrm{ml}$ heparin (as co-receptor for FGF signaling) for the assays of inhibitory or synergistic effects of GAGs on FGF10-FGFR2b reactivity. FGF10 (1000 pM) in 10\%
BSA and $0-5 \mu \mathrm{g} / \mathrm{ml}(0,0.02,0.08,0.30,1.25$, and $5.00 \mu \mathrm{g} / \mathrm{ml}$ ) of HS, DiS HS, TriS HS, CSA or heparin were added to each well in duplicates for each group. The cells were incubated at $37^{\circ} \mathrm{C}$ for $36-48 \mathrm{~h}$ before being assayed for cell number/viability with the CCK- 8 kit (Sigma) following the manufacturer's instruction. Twoway ANOVA shows that heparin is different from all other GAGs, $p<0.001$. DiS HS was synthesized from $N$ sulfo heparosan with modification using C5-epimerase and 2-O-sulfotransferase (2OST) following our previously reported procedures [72]. TriS HS (NS2S6S) was synthesized from $\mathrm{N}$-sulfo heparosan with subsequent modification with $\mathrm{C} 5$-epimerase, 2-O-sulfotransferase, and 6-O-sulfotransferases (6OST1/6OST3) [72].

\section{$3 D$ hydrogel cell culture}

A hydrogel cell culture system was used to mimic the extracellular matrix context in the dental epithelium (Fig. 7a). Briefly, $1.0 \mu \mathrm{g} / \mathrm{ml}, 3.0 \mu \mathrm{g} / \mathrm{ml}$, or $5.0 \mu \mathrm{g} / \mathrm{ml}$ of each GAGs (CSA, CSB, HS, Des-2, and Des-6) in $10 \times$ RPMI1640 and $2.0 \times 10^{4} / \mathrm{ml} \mathrm{BaF3-FGFR2b}$ cells were mixed with premade collagen solution $(2 \mathrm{mg} / \mathrm{ml}, \mathrm{C} 4243$, Sigma). In each well of 24-well plates, $500 \mu \mathrm{l}$ of such mixture was dispensed and incubated at $37^{\circ} \mathrm{C}$ for $1 \mathrm{~h}$ to allow gelation. The hydrogel cylinders were then maintained in RPMI culture media supplemented with $100 \mathrm{ng} / \mathrm{ml}$ recombinant human FGF-10 (Invitrogen) for further analyses.

\section{Cell viability assay}

Hydrogel was collected for cell viability assay on day 2 of culture using a Live/Dead Viability Kit (Invitrogen). After washing in PBS for $5 \mathrm{~min}$, the hydrogel was incubated in $2 \mu \mathrm{M}$ calcein $\mathrm{AM}$ and $4 \mu \mathrm{M}$ ethidium homodimer- 1 prepared in PBS in the dark at $37^{\circ} \mathrm{C}$ for $40 \mathrm{~min}$, then washed in PBS for imaging. Fluorescent images were obtained with a Zeiss LSM 880 two-photon microscopy (Visible laser lines: 406 and $488 \mathrm{~nm}$ ). The number of live cells in each sample was counted in 3D hydrogel chips reconstructed from 6 randomly selected areas using Imaris 9.0 (Bitplane) and subjected to statistical analysis.

\section{Statistics}

The data was expressed as mean \pm SD of at least 6 determinations in all experiments unless otherwise indicated. We used 2-sample $t$ tests to evaluate the pairs of samples and independent-samples $T$ test for the independent samples. Before performing $t$ test, normal distribution was verified by Levene's test using SPSS (IBM, NY, USA). Two-way ANOVA was used to compare multiple groups. A $P$ value of $<0.05$ was considered to indicate statistically significant differences. 


\section{Supplementary information}

Supplementary information accompanies this paper at https://doi.org/10. 1186/s12915-020-00813-4.

Additional file 1: Figure S1. GAGs commit the cell fate of dental epithelium at the initial stage of tooth development. A K14t ${ }^{\text {rtTA }}$, tetO $\mathrm{O}^{\mathrm{Cre}}$ and Fam20B-flox mice were crossbred to ultimately generate $\mathrm{K}^{\mathrm{rtTA}}$; tetO $^{\mathrm{Cre}}$;Fam2OB $\mathrm{B}^{\mathrm{fl} / \mathrm{fl}}$ mice. B Doxycycline (Dox) was administrated to the resultant mice at $2 \mathrm{mg} / \mathrm{kg}$ at designated time points (E10.5-E14.5) to induce Cre-loxP mediated Fam20B deletion from the dental epithelium: the transactivator rtTA driven by epithelium-specific Keratin-14 promoter recognizes tet $O$ sequences in the presence of doxycycline and initiates the transcription of CRE recombinase, thereby deleting Fam20B allele between two loxp sites.

Additional file 2: Figure S2. The dynamics of Sox2 expression during supernumerary incisor formation. IHC staining of Sox2 was performed on sagittal sections of lower incisors. Ib $\leftrightarrow$ g indicates the orientation of labial and lingual sides. A, B At E12.5, the Fam20b-deficient dental epithelium started showing more Sox2 expression than normal. C, D At E13.5, the control incisors showed reduced expression of Sox 2 in the dental epithelium, while the Fam20b-deficient dental epithelium had strong expression of Sox2 in the lingual side of the enamel organ (arrow). E-H At E14.5 and E15.5, the control incisors gradually lost Sox2 expression from the lingual side of enamel organ. In contrast, the Fam20B-deficient incisors showed strong ectopic Sox2 expression at the lingual side of enamel organ (arrows). Scale bars, $50 \mu \mathrm{m}$ in $A$ and $B, 100 \mu \mathrm{m}$ in $\mathrm{C}$ and $\mathrm{D}$, $200 \mu \mathrm{m}$ in $\mathrm{E}$ and $\mathrm{F}, 400 \mu \mathrm{m}$ in $\mathrm{G}$ and $\mathrm{H}$.

Additional file 3: Figure S3. Inactivation of Sox2 from the dental epithelium partially rescued the supernumerary tooth phenotype in $\mathrm{K}^{\mathrm{Cre} / \mathrm{H}}$;Fam2OB ${ }^{f / f f}$ mice. We introduced Sox $2^{f / f l}$ allele into $\mathrm{K}^{\mathrm{Cre} / \mathrm{+}}$;Fam2OB ${ }^{\mathrm{fl} / \mathrm{fl}}$ mice to inactivate both Sox2 and Fam20B in the dental epithelium. The double knockout $\left(\mathrm{K}_{14}{ }^{\mathrm{Cre} /{ }^{+}} ; \mathrm{Fam}_{20 B^{\mathrm{fl} / f l} ;}\right.$;SOX2 $\left.{ }^{\mathrm{fl} / \mathrm{fl}}\right)$ mice showed reduced number and size of supernumerary teeth (black arrows)

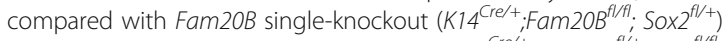

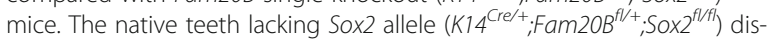
played a smaller size than normal (white arrows).

Additional file 4: Figure S4. FAM20B-catalyzed GAGs regulate the homeostasis of Sox $2^{+}$cells in a non-autonomous manner. A To validate the efficiency of the Sox2-CreER, we crossbred the CreER line with Rosa26-tdTomato indicator mice and induced the Cre expression with single I.P. injection of tamoxifen at E11.5. The embryos were collected at E12.5 and subjected to cryosection for fluorescence assay. On the same cryosections, Sox2-expressing cells were labeled by immunofluorescence using anti-Sox2 antibody and EGFP-conjugated secondary antibody. The Cre activity indicated by Tomato fluorescence (red) was strongly present in the dental epithelium (arrows) and oral epithelium, as well as nasal mucosa and palatal epithelium. The antibody-labeled Sox2-expressing cells (green) mostly overlapped with CreER active cells (red) and showed yellow on the merged channel. CreER-active cells showed overall broader range than the antibody-labeled Sox2(+) cells in the dental epithelium (especially in the distal side) and nasal mucosa, indicating that the efficiency of Sox2-CreER was strong enough for deleting floxed alleles from the Sox2-expressing cells. $n$, nose; p, palate; m, mandible. B To determine the regulatory manner of GAGs on Sox2 $(+)$ cell homeostasis, we inactivated Fam20B from Sox2(+) lineage using Sox2-CreER. Tamoxifen was ad-

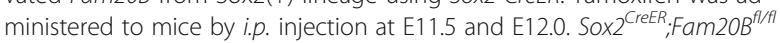
mice did not recapitulate the replacement tooth phenotype, suggesting that GAGs regulate the homeostasis of Sox2(+) cells in a nonautonomous manner.

Additional file 5: Figure S5. WNT signaling was not changed in the Fam20B-deficient incisors at the early stage of tooth development. A, B Immunohistochemistry staining of LEF1 on the coronal sections of lower incisors showed no differences between the Fam20B-deficient and control incisors at E12.5. $\mathrm{d} \leftrightarrow \mathrm{m}$ indicates the orientation of distal and mesial sides. C, D Whole-mount staining of BAT-Gal indicator on E12.5 mandibles showed no differences between the Fam20B-mutants and controls. The yellow dotted lines plotted the areas of LacZ positive staining. $\mathbf{E}, \mathbf{F}$ Immunohistochemistry staining of $\beta$-Catenin on the coronal sections of lower incisors showed no differences between the Fam20B- deficient and control incisors at E12.5. G, H In situ hybridyzation staining of Wnt5a on the coronal sections of lower incisors showed no differences between the Fam20B-deficient and control incisors at E13.5. The yellow dotted lines in $\mathrm{E}-\mathrm{H}$ indicate the boarder line between the dental epithelium and the dental mesenchyme. Scale bars, $100 \mu \mathrm{m}$.

Additional file 6: Figure S6. BMP signaling was not changed in the Fam20B-deficient incisors at the early stage of tooth development. A-D In situ hybridyzation staining of $\mathrm{Msx}-1$ on the coronal sections of lower incisors showed no differences between the Fam20B-deficient and control incisors at E12.5 and E13.5. $\mathrm{d} \leftrightarrow \mathrm{m}$ indicates the orientation of distal and mesial sides. The yellow dotted lines indicate the boarder line between the dental epithelium and the dental mesenchyme. E, F Whole-mount staining of BRE-LacZ indicator on E12.5 mandibles showed no differences between the incisors of Fam20B-mutants and controls. The yellow dotted lines plotted the areas of LacZ positive staining in the lower incisors. $\mathbf{G}, \mathbf{H}$ Whole-mount ISH staining of Bmp4 on E12.5 mandibles showed no differences between the incisors of Fam20B-mutants and controls. I, J Immunohistochemistry staining of p-SMAD1/5 on the coronal sections of lower incisors showed no differences between the Fam20B-deficient and control incisors at E12.5. K, L In situ hybridyzation staining of Sostdc-1 on the coronal sections of lower incisors showed no differences between the Fam20B-deficient and control incisors at E12.5. Scale bars, $100 \mu \mathrm{m}$.

Additional file 7: Figure S7. The transcriptional expression of Fgf10, Fgfr $2 b$ and Fgf9 was not changed in the Fam20B-deficient incisors at the early stage of tooth development. A- F RNAScope staining of Fgf10, Fgfr $2 b$ and Fgf9 on the coronal sections of lower incisors showed no differences between the Fam20B-deficient and control incisors at E12.5. The dotted lines indicate the boarder line between the dental epithelium and the dental mesenchyme. G Semi-quantitative analysis of RNAScope results showed no significant differences in the transcriptional expression of Fgf10, Fgfr2b and Fgf9 between the Fam20B-deficient (KO) and control (WT) incisors. Scale bars, $100 \mu \mathrm{m}$ in A and B; $50 \mu \mathrm{m}$ in C-F.

Additional file 8: Figure S8. Inhibition of Fgfr2b in the Fam20Bdeficient dental epithelium reduced the expanded expression scope of Shh back to the normal size. Scale bars, $250 \mu \mathrm{m}$.

Additional file 9: Figures S9A-S9B. Fig. S9A-[GAGs did not show synergistic effects on FGF10-FGFR2b signaling]. Fig. S9B-[GAGs did not show inhibitory effects on FGF10-FGFR2b signaling]. HS and CS did not show significant synergistic or inhibitory effects on FGF10-FGFR2b signaling in BaF3 cells. A BaF3 cells expressing FGFR2b were cultured in RPMI 1640 media supplemented with 1000 pM FGF10 and 0-5 ng/ml GAGs (HS/HS2S/HS6S/CSA/heparin) for $45 \mathrm{~h}$. Heparin (positive control) showed significant synergistic effects on FGFR2b signaling $(P<0.001)$, while HS/ $\mathrm{HS} 2 \mathrm{~S} / \mathrm{HS} 6 \mathrm{~S} / \mathrm{CSA}$ groups did not show any significant synergistic effects $(P>0.05)$. B BaF3-FGFR2b cells were cultured in RPMI 1640 media supplemented with 1000 pM FGF10 and $1.5 \mu \mathrm{g} / \mathrm{ml}$ heparin to boost the baseline of FGFR2b signaling activity (indicated by cell viability OD value). HS/ CSA/CSC/CSE/LMW heparin (0-5 ng/ml) supplemented to the culture media did not show any inhibitory effects on FGFR2b signaling $(P>0.05)$. Two-way ANOVA was used to evaluate the differences among groups.

Additional file 10: Figure S10. Live image of $\mathrm{BaF} 3$ cells in the hydrogel. After $48 \mathrm{~h}$ of culture, BaF3-FGFR2b cells were stained with Live/ Dead Staining. Calcein AM in Green represents live cells. DAPI was used for counter staining. Live images of the cells in hydrogel were acquired by confocal microscopy and reconstructed with Imaris 9.0. The number of live cells in each sample was counted from 3D hydrogel chips reconstructed from 6 randomly selected areas for statistical analysis.

\section{Acknowledgements}

We thank Dr. Leif Oxburgh (Maine Medical Center Research Institute) for providing the BRE-LaCZ indicator mice and Dr. Yiping Chen (Tulane University) for his critical reading of this manuscript.

\section{Authors' contributions}

The hypotheses and experimental design for this research was developed by J.W., R.L., D.O., and X.W. Experiments and data analysis were undertaken by J.W., Y.T., L.H., C.L., T.S., L.L., Y.Y., B.L., and H.Z. J.W., L.H., R.D., S.M., R.K., J.F., D.O., O.K., F.Z., R.L., and X.W. were involved in figure production and drafting the manuscript. All authors read and approved the final manuscript. 


\section{Funding}

This study was supported by NIH grant DE026461 and DE028345 (XW), DK111958 (RJL), and HL11190 (DMO).

\section{Availability of data and materials}

All data generated during this study are included in this published article and its additional files. Raw data and materials will be available at request.

\section{Ethics approval and consent to participate}

All experimental procedures were conducted with the approval of Texas A\&M University Animal Care and Ethics Committee and conformed to the National Health and Medical Research guidelines for animal handling.

\section{Competing interests}

The authors declare that they have no competing interests.

\section{Author details}

'Southern Medical University Hospital of Stomatology, Guangzhou 510280, Guangdong, China. ${ }^{2}$ Department of Biomedical Sciences, Texas A\&M University College of Dentistry, 3302 Gaston Ave, Dallas, TX 75246, USA. ${ }^{3}$ West China Hospital of Stomatology, Sichuan University, Chengdu 610000, Sichuan, China. ${ }^{4}$ Department of Oral Pathology, College of Stomatology, Dalian Medical University, Dalian 116044, Liaoning, China. ${ }^{5}$ Department of Developmental Biology, Washington University School of Medicine, St. Louis, MO 63110, USA. ${ }^{6}$ Department of Chemistry and Chemical Biology, Rensselaer Polytechnic Institute, Troy, NY 12180, USA. ${ }^{7}$ School of Dentistry, University of Utah, Salt Lake City, UT 84108, USA. ${ }^{8}$ Department of Dermatology, Perelman School of Medicine, University of Pennsylvania, Philadelphia, PA 19104, USA. ${ }^{9}$ Stowers Institute for Medical Research, Kansas City, MO 64110, USA.

${ }^{10}$ Department of Anatomy and Cell Biology, Kansas University Medical Center, Kansas City, KS 66160, USA. ${ }^{11}$ Department of Orofacial Sciences and Program in Craniofacial Biology, University of California, San Francisco, San Francisco, CA 94143, USA. ${ }^{12}$ Institute for Human Genetics, University of California, San Francisco, San Francisco, CA 94143, USA.

Received: 5 December 2019 Accepted: 17 June 2020

Published online: 14 July 2020

\section{References}

1. Vainio S, Lin Y. Organogenesis: coordinating early kidney development: lessons from gene targeting. Nat Rev Genet. 2002;3(7):533.

2. Balic A, Thesleff I. Tissue interactions regulating tooth development and renewal. Curr Top Dev Biol. 2015:115:157-86.

3. Thesleff I, Barrach HJ, Foidart JM, Vaheri A, Pratt RM, Martin GR. Changes in the distribution of type IV collagen, laminin, proteoglycan, and fibronectin during mouse tooth development. Dev Biol. 1981;81(1):182-92.

4. Thesleff I, Hurmerinta K. Tissue interactions in tooth development Differentiation. 1981;18(1-3):75-88.

5. Thesleff I, Vaahtokari A, Partanen AM. Regulation of organogenesis. Common molecular mechanisms regulating the development of teeth and other organs. Int J Dev Biol. 1995;39(1):35-50.

6. Bai XM, Van der Schueren B, Cassiman JJ, Van den Berghe H, David G. Differential expression of multiple cell-surface heparan sulfate proteoglycans during embryonic tooth development. J Histochem Cytochem. 1994;42(8): 1043-54.

7. Wu J, Li H, Han L, Sun T, Tian Y, Wang X. The spatiotemporal expression pattern of Syndecans in murine embryonic teeth. Gene Expr Patterns 2020; 36:119109. https://doi.org/10.1016/j.gep.2020.119109.

8. Mythreye K, Blobe GC. Proteoglycan signaling co-receptors: roles in cell adhesion, migration and invasion. Cell Signal. 2009;21(11):1548-58.

9. Koike T, Izumikawa T, Tamura Jl, Kitagawa H. FAM20B is a kinase that phosphorylates xylose in the glycosaminoglycan-protein linkage region. Biochem J. 2009:421(2):157-62.

10. Wen J, Xiao J, Rahdar M, Choudhury BP, Cui J, Taylor GS, Esko JD, Dixon JE Xylose phosphorylation functions as a molecular switch to regulate proteoglycan biosynthesis. P Natl Acad Sci USA. 2014;111(44):15723-8.

11. Vogel P, Hansen GM, Read RW, Vance RB, Thiel M, Liu J, Wronski TJ, Smith DD, Jeter-Jones S, Brommage R. Amelogenesis imperfecta and other biomineralization defects in Fam20a and Fam20c null mice. Vet Pathol. 2012;49(6):998-1017.
12. Tian Y, Ma P, Liu C, Yang X, Crawford DM, Yan W, Bai D, Qin C, Wang X. Inactivation of Fam20B in the dental epithelium of mice leads to supernumerary incisors. Eur J Oral Sci. 2015;123(6):396-402.

13. Thesleff I, Jalkanen M, Vainio S, Bernfield M. Cell surface proteoglycan expression correlates with epithelial-mesenchymal interaction during tooth morphogenesis. Dev Biol. 1988;129(2):565-72.

14. Vainio S, Jalkanen $M$, Thesleff I. Syndecan and tenascin expression is induced by epithelial-mesenchymal interactions in embryonic tooth mesenchyme. J Cell Biol. 1989;108(5):1945-53.

15. Salmivirta M, Elenius K, Vainio S, Hofer U, Chiquet-Ehrismann R, Thesleff I, Jalkanen M. Syndecan from embryonic tooth mesenchyme binds tenascin. J Biol Chem. 1991;266(12):7733-9.

16. Vainio S, Jalkanen M, Vaahtokari A, Sahlberg C, Mali M, Bernfield M, Thesleff I. Expression of syndecan gene is induced early, is transient, and correlates with changes in mesenchymal cell proliferation during tooth organogenesis. Dev Biol. 1991;147(2):322-33.

17. Mizumoto S, Yamada S, Sugahara K. Human genetic disorders and knockout mice deficient in glycosaminoglycan. Biomed Res Int. 2014; 2014:495764.

18. Wang XP, Fan J. Molecular genetics of supernumerary tooth formation. Genesis. 2011:49(4):261-77.

19. Bei M. Molecular genetics of tooth development. Curr Opin Genet Dev. 2009;19(5):504-10.

20. Liu X, Li N, Zhang H, Liu J, Zhou N, Ran C, Chen X, Lu Y, Wang X, Qin C, Xiao J. Inactivation of Fam20b in the neural crest-derived mesenchyme of mouse causes multiple craniofacial defects. Eur J Oral Sci. 2018;126(5):433-6.

21. Juuri E, Saito K, Ahtiainen L, Seidel K, Tummers M, Hochedlinger K, Klein OD, Thesleff I, Michon F. Sox2+ stem cells contribute to all epithelial lineages of the tooth via Sfrp5+ progenitors. Dev Cell. 2012;23(2):317-28.

22. Juuri E, Jussila M, Seidel K, Holmes S, Wu P, Richman J, Heikinheimo K, Chuong CM, Arnold K, Hochedlinger K, Klein O. Sox2 marks epithelial competence to generate teeth in mammals and reptiles. Development. 2013;140(7):1424-32

23. Thesleff I, Nieminen P. Tooth morphogenesis and cell differentiation. Curr Opin Cell Biol. 1996:8(6):844-50.

24. Jussila M, Thesleff I. Signaling networks regulating tooth organogenesis and regeneration, and the specification of dental mesenchymal and epithelial cell lineages. CSH perspect Biol. 2012;4(4):a008425

25. Lan $Y$, Jia S, Jiang R. Molecular patterning of the mammalian dentition. Semin Cell Dev Biol. 2014;25:61-70.

26. Du W, Du W, Yu H. The role of fibroblast growth factors in tooth development and incisor renewal. Stem Cell Int. 2018;2018:7549160.

27. Klein OD, Minowada G, Peterkova R, Kangas A, Yu BD, Lesot H, Peterka M, Jernvall J, Martin GR. Sprouty genes control diastema tooth development via bidirectional antagonism of epithelial-mesenchymal FGF signaling. Dev Cell. 2006:11(2):181-90.

28. Jackman WR, Davies SH, Lyons DB, Stauder CK, Denton-Schneider BR, Jowdry A, Aigler SR, Vogel SA, Stock DW. Manipulation of Fgf and Bmp signaling in teleost fishes suggests potential pathways for the evolutionary origin of multicuspid teeth. Evol Dev. 2013;15(2):107-18.

29. Hokuto I, Perl AK, Whitsett JA. Prenatal, but not postnatal, inhibition of fibroblast growth factor receptor signaling causes emphysema. J Biol Chem. 2002;278(1):415-21.

30. Li G, Li L, Tian F, Zhang L, Xue C, Linhardt RJ. Glycosaminoglycanomics of cultured cells using a rapid and sensitive LC-MS/MS approach. ACS Chem Biol. 2015;10(5):1303-10

31. Xu D, Esko JD. Demystifying heparan sulfate-protein interactions. Annu Rev Biochem. 2014;83:129-57.

32. Zhang F, Zheng L, Cheng S, Peng Y, Fu L, Zhang X, Linhardt RJ. Comparison of the interactions of different growth factors and glycosaminoglycans. Molecules. 2019:24(18):3360.

33. Ornitz DM, Xu J, Colvin JS, McEwen DG, MacArthur CA, Coulier F, Gao G, Goldfarb M. Receptor specificity of the fibroblast growth factor family. J Biol Chem. 1996;271(25):15292-7

34. Ornitz DM, Itoh $\mathrm{N}$. The fibroblast growth factor signaling pathway. Wiley Interdiscip Rev Dev Biol. 2015;4(3):215-66.

35. Chu EY, Hens J, Andl T, Kairo A, Yamaguchi TP, Brisken C, Glick A, Wysolmerski JJ, Millar SE. Canonical WNT signaling promotes mammary placode development and is essential for initiation of mammary gland morphogenesis. Development. 2004;131(19):4819-29. 
36. Munne PM, Tummers M, Järvinen E, Thesleff I, Jernvall J. Tinkering with the inductive mesenchyme: Sostdc1 uncovers the role of dental mesenchyme in limiting tooth induction. Development. 2009;136(3):393-402.

37. Ahn Y, Sanderson BW, Klein OD, Krumlauf R. Inhibition of Wnt signaling by Wise (Sostdc1) and negative feedback from Shh controls tooth number and patterning. Development. 2010;137(19):3221-31.

38. Järvinen $\mathrm{E}$, Birchmeier W, Taketo MM, Jernvall J, Thesleff I. Continuous tooth generation in mouse is induced by activated epithelial Wnt/ $\beta$-catenin signaling. Proc Natl Acad Sci U S A. 2006;103(49):18627-32.

39. Wang XP, O'Connell DJ, Lund JJ, Saadi I, Kuraguchi M, Turbe-Doan A, Cavallesco R, Kim H, Park PJ, Harada H, Kucherlapati R. Apc inhibition of Wnt signaling regulates supernumerary tooth formation during embryogenesis and throughout adulthood. Development. 2009;136(11):1939-49.

40. Xavier GM, Patist AL, Healy C, Pagrut A, Carreno G, Sharpe PT, MartinezBarbera JP, Thavaraj S, Cobourne MT, Andoniadou CL. Activated WNT signaling in postnatal SOX2-positive dental stem cells can drive odontoma formation. Sci Rep. 2015:5:14479.

41. Popa EM, Buchtova M, Tucker AS. Revitalising the rudimentary replacement dentition in the mouse. Development. 2019;146(3):dev171363.

42. Smith MM, Fraser GJ, Mitsiadis TA. Dental lamina as source of odontogenic stem cells: evolutionary origins and developmental control of tooth generation in gnathostomes. J Exp Zool Part B. 2009;312(4):260-80.

43. Chavez MG, Hu J, Seidel K, Li C, Jheon A, Naveau A, Horst O, Klein OD. Isolation and culture of dental epithelial stem cells from the adult mouse incisor. J Vis Exp. 2014;87:e51266.

44. Li J, Feng J, Liu Y, Ho TV, Grimes W, Ho HA, Park S, Wang S, Chai Y. BMPSHH signaling network controls epithelial stem cell fate via regulation of its niche in the developing tooth. Dev Cell. 2015;33(2):125-35.

45. Sun Z, Yu W, Navarro MS, Sweat M, Eliason S, Sharp T, Liu H, Seidel K, Zhang L, Moreno M, Lynch T. Sox2 and Lef-1 interact with Pitx2 to regulate incisor development and stem cell renewal. Development. 2016;143(22):4115-26.

46. Harada H, Mitsuyasu T, Toyono T, Toyoshima K. Epithelial stem cells in teeth. Odontology. 2002;90(1):0001-6.

47. Coutu DL, Galipeau J. Roles of FGF signaling in stem cell self-renewal, senescence and aging. Aging. 2011;3(10):920.

48. Volckaert T, Yuan T, Chao CM, Bell H, Sitaula A, Szimmtenings L, El Agha E, Chanda D, Majka S, Bellusci S, Thannickal VJ. Fgf10-Hippo epithelialmesenchymal crosstalk maintains and recruits lung basal stem cells. Dev Cell. 2017:43(1):48-59.

49. Lombaert IM, Abrams SR, Li L, Eswarakumar VP, Sethi AJ, Witt RL, Hoffman MP. Combined KIT and FGFR2b signaling regulates epithelial progenitor expansion during organogenesis. Stem Cell Rep. 2013;1(6):604-19.

50. Sanz-Navarro M, Seidel K, Sun Z, Bertonnier-Brouty L, Amendt BA, Klein OD, Michon F. Plasticity within the niche ensures the maintenance of a Sox2+ stem cell population in the mouse incisor. Development. 2018;145(1): dev155929.

51. Pickford CE, Holley RJ, Rushton G, Stavridis MP, Ward CM, Merry CL. Specific glycosaminoglycans modulate neural specification of mouse embryonic stem cells. Stem Cells. 2011;29(4):629-40.

52. Kraushaar DC, Dalton S, Wang L. Heparan sulfate: a key regulator of embryonic stem cell fate. Biol Chem. 2013;394(6):741-51.

53. Patel VN, Knox SM, Likar KM, Lathrop CA, Hossain R, Eftekhari S, Whitelock JM, Elkin M, Vlodavsky I, Hoffman MP. Heparanase cleavage of perlecan heparan sulfate modulates FGF10 activity during ex vivo submandibular gland branching morphogenesis. Development. 2007; 134(23):4177-86.

54. Qu X, Carbe C, Tao C, Powers A, Lawrence R, van Kuppevelt TH, Cardoso W, Grobe K, Esko JD, Zhang X. Lacrimal gland development and Fgf10Fgfr2b signaling are controlled by 2-O-and 6-O-sulfated heparan sulfate. J Biol Chem. 2011;286(16):14435-44.

55. Li Y, Sun C, Yates EA, Jiang C, Wilkinson MC, Fernig DG. Heparin binding preference and structures in the fibroblast growth factor family parallel their evolutionary diversification. Open Biol. 2016;6(3):150275.

56. Lindahl U, Li JP. Interactions between heparan sulfate and proteins-design and functional implications. Int Rev Cel Mol Biol. 2009:276:105-59.

57. Li JP, Kusche-Gullberg M. Heparan sulfate: biosynthesis, structure, and function. Int Rev Cell Mol Biol. 2016:325:215-73.

58. Lewis AE, Vasudevan HN, O'Neill AK, Soriano P, Bush JO. The widely used Wnt1-Cre transgene causes developmental phenotypes by ectopic activation of Wnt signaling. Dev Biol. 2013;379(2):229-34.
59. Nguyen H, Rendl M, Fuchs E. Tcf3 governs stem cell features and represses cell fate determination in skin. Cell. 2006:127(1):171-83.

60. Perl AK, Wert SE, Nagy A, Lobe CG, Whitsett JA. Early restriction of peripheral and proximal cell lineages during formation of the lung. Proc Natl Acad Sci. 2002;99(16):10482-7.

61. Madisen L, Zwingman TA, Sunkin SM, Oh SW, Zariwala HA, Gu H, Ng LL, Palmiter RD, Hawrylycz MJ, Jones AR, Lein ES. A robust and highthroughput Cre reporting and characterization system for the whole mouse brain. Nat Neurosci. 2010;13(1):133-40.

62. Maretto S, Cordenonsi M, Dupont S, Braghetta P, Broccoli V, Hassan AB, Volpin D, Bressan GM, Piccolo S. Mapping Wnt/B-catenin signaling during mouse development and in colorectal tumors. Proc Natl Acad Sci. 2003; 100(6):3299-304.

63. Bai CB, Auerbach W, Lee JS, Stephen D, Joyner AL. Gli2, but not Gli1, is required for initial Shh signaling and ectopic activation of the Shh pathway. Development. 2002;129(20):4753-61.

64. Goodrich LV, Milenković L, Higgins KM, Scott MP. Altered neural cell fates and medulloblastoma in mouse patched mutants. Science. 1997;277(5329): 1109-13.

65. Arnold K, Sarkar A, Yram MA, Polo JM, Bronson R, Sengupta S, Seandel M, Geijsen N, Hochedlinger K. Sox2+ adult stem and progenitor cells are important for tissue regeneration and survival of mice. Cell Stem Cell. 2011; 9(4):317-29.

66. Shaham O, Smith AN, Robinson ML, Taketo MM, Lang RA, Ashery-Padan R Pax6 is essential for lens fiber cell differentiation. Development. 2009; 136(15):2567-78

67. Jing D, Zhang S, Luo W, Gao X, Men Y, Ma C, Liu X, Yi Y, Bugde A, Zhou BO, Zhao Z. Tissue clearing of both hard and soft tissue organs with the PEGASOS method. Cell Res. 2018;28(8):803-18.

68. Wu J, Feng JQ, Wang $X$. In situ hybridization on mouse paraffin sections using DIG-labeled RNA probes. In: Odontogenesis 2019. New York: Humana Press; 2019. p. p163-71.

69. Wu J, Wang X. Whole-mount in situ hybridization of mouse embryos using DIG-labeled RNA probes. In: Odontogenesis 2019. New York: Humana Press; 2019. p. p151-9.

70. Sun X, Li L, Overdier KH, Ammons LA, Douglas IS, Burlew CC, Zhang F, Schmidt EP, Chi L, Linhardt RJ. Analysis of total human urinary glycosaminoglycan disaccharides by liquid chromatography-tandem mass spectrometry. Anal Chem. 2015:87(12):6220-7.

71. Santos-Ocampo S, Colvin JS, Chellaiah A, Ornitz DM. Expression and biological activity of mouse fibroblast growth factor-9. J Biol Chem. 1996; 271(3):1726-31.

72. Zhang Z, McCallum SA, Xie J, Nieto L, Corzana F, Jiménez-Barbero J, Chen M, Liu J, Linhardt RJ. Solution structures of chemoenzymatically synthesized heparin and its precursors. J Am Chem Soc. 2008;130(39):12998-3007.

\section{Publisher's Note}

Springer Nature remains neutral with regard to jurisdictional claims in published maps and institutional affiliations.
Ready to submit your research? Choose BMC and benefit from:

- fast, convenient online submission

- thorough peer review by experienced researchers in your field

- rapid publication on acceptance

- support for research data, including large and complex data types

- gold Open Access which fosters wider collaboration and increased citations

- maximum visibility for your research: over $100 \mathrm{M}$ website views per year

At $\mathrm{BMC}$, research is always in progress.

Learn more biomedcentral.com/submissions 